\title{
14. PLANKTONIC FORAMINIFERS FROM THE BERMUDA RISE, DEEP SEA DRILLING PROJECT LEGS 51, 52, AND 53
}

\author{
Gregory A. Miles, Exxon Company U.S.A., Houston, Texas \\ and \\ William N. Orr, University of Oregon, Eugene, Oregon
}

\section{INTRODUCTION}

During Legs 51, 52, and 53 of the Deep Sea Drilling Project, foraminifer-bearing sediments were recovered from seven holes at Sites 417 and 418 near the southern end of the Bermuda Rise (Figure 1). Holes 417A, 417D, 418A, and $418 \mathrm{~B}$ were drilled through the entire sedimentary section to acoustic basement, whereas Holes $417,417 \mathrm{~B}$, and 418 were single-core mudline holes. These drilling objectives were situated far below the calcium carbonate compensation depth (CCD) in water depths ranging from 5468 to 5514 meters.

We examined more than 300 samples during this study, 47 of which contain planktonic foraminifers. Where core recovery was complete, one sample was taken from each section (1.5 of core), and an additional sample was collected from each core catcher. In favorable lithologies, especially in the Cretaceous section, samples were taken at closer intervals. The samples were processed by boiling them in water with small amounts of automatic dishwasher detergent and hydrogen peroxide. Subsequently, they were wet-sieved through a $44-\mu \mathrm{m}$ mesh screen.

Foraminifers were recovered only from Quaternary brown clay and from Lower to mid-Cretaceous claystone and chalk. The Quaternary assemblages, most of which are moderately to strongly dissolved, were recovered from Holes 417, 417A, 417B, 417D, 418, and 418B. Well-preserved Cretaceous assemblages occur in Holes 417D, 418A, and 418B. The Cretaceous faunas range from lower Aptian to lower Cenomanian and, although sporadic in occurrence, occasionally contain abundant planktonic foraminifers.

\section{FAUNAL COMPOSITION AND PRESERVATION}

\section{Holes 417 and 417A (Table 1)}

At Hole 417, we recovered a surficial punch core containing about 2 meters of pelagic clay. The core was taken in 5468 meters of water. At Hole 417A, we drilled a single-bit pilot hole about 200 meters from Hole 417 . Twenty-one cores were taken in the 208-meter sedimentary section above acoustic basement.

Planktonic foraminifers occur only in Cores 417-1, 417A-1, and 417A-2. The faunas are well preserved at some levels, but strongly dissolved at others. Most are dominated by the solution-resistant species Globigerinoides conglobatus (Brady) and Globigerinoides sacculifer (Brady). The occurrence of Globorotalia truncatulinoides (d'Orbigny) indicates that these cores are Quaternary.
Sediments below Core 417A-2 consist of brown pelagic clays, zeolitic clays, and multicolored clays. Radiolarians recovered from these sediments place Cores 14 through 18 in the middle Eocene and Cores 19 through 21 in the Upper Cretaceous.

\section{Holes 417B and 417D (Table 1)}

Gne core of pelagic clay was recovered at Hole 417B before the hole was abandoned in favor of a deep penetration attempt at Hole 417D. Samples from this core contain assemblages of moderately dissolved Quaternary planktonic foraminifers (see Table 2).

At Hole 417D, we penetrated 343 meters of sediment and recovered 21 cores before encountering basaltic basement. Coring was intermittent to a depth of approximately 200 meters, then was continuous to basement. The section consists of zeolitic clay, pyritic claystone, and minor lithologies, including chalk and "radiolarian sandstone." Planktonic foraminifers were recovered from Cores 1, 17, 19, 20, and 21. Radiolarians of the middle Eocene Podocyrtis mitra Zone were encountered in Core 5, and Cretaceous radiolarians were recovered from Sample 417D-7, CC and numerous other samples downhole to acoustic basement.

Planktonic foraminifer faunas from Core 417D-1 are dominated by Globigerinoides conglobatus, G. ruber, and $G$. sacculifer. Assemblages in most of the core show signs of strong dissolution; however, those from Sections 3 and 4 are well preserved and contain as many as 18 species. This core is assigned to the Quaternary, based on the presence of Globorotalia truncatulinoides.

Cretaceous planktonic foraminifers occur in Cores 417D-17, 19, 20, and 21. These fossils are abundant only in the upper $15 \mathrm{~cm}$ of Section 417D-17-1, in Sample 417D20-2, 20-22 cm, and in Sample 417D-21-3, 133-135 cm. Other samples from Cores 417D-17 through 21 contain sparse assemblages or are barren.

The top $15 \mathrm{~cm}$ of Section 417D-17-1 consist of foraminifer-bearing nannofossil chalk. Three samples from this interval contain abundant Hedbergella planispira (Tappan), Hedbergella delrioensis (Carsey), and Hedbergella yezoana Takayanagi and Iwamoto; numerous specimens of Globigerinelloides bentonensis (Morrow), Hedbergella amabilis Loeblich and Tappan, and Rotalipora ticinensis (Gandolfi); and rare specimens of Clavihedbergella moremani (Cushman), Clavihedbergella simplex (Morrow), and Schackoina cenomana (Schacko). Hedbergella delrioensis and $H$. planispira are long-ranging species which are not particularly age diagnostic. Rotalipora ticinensis, perhaps 


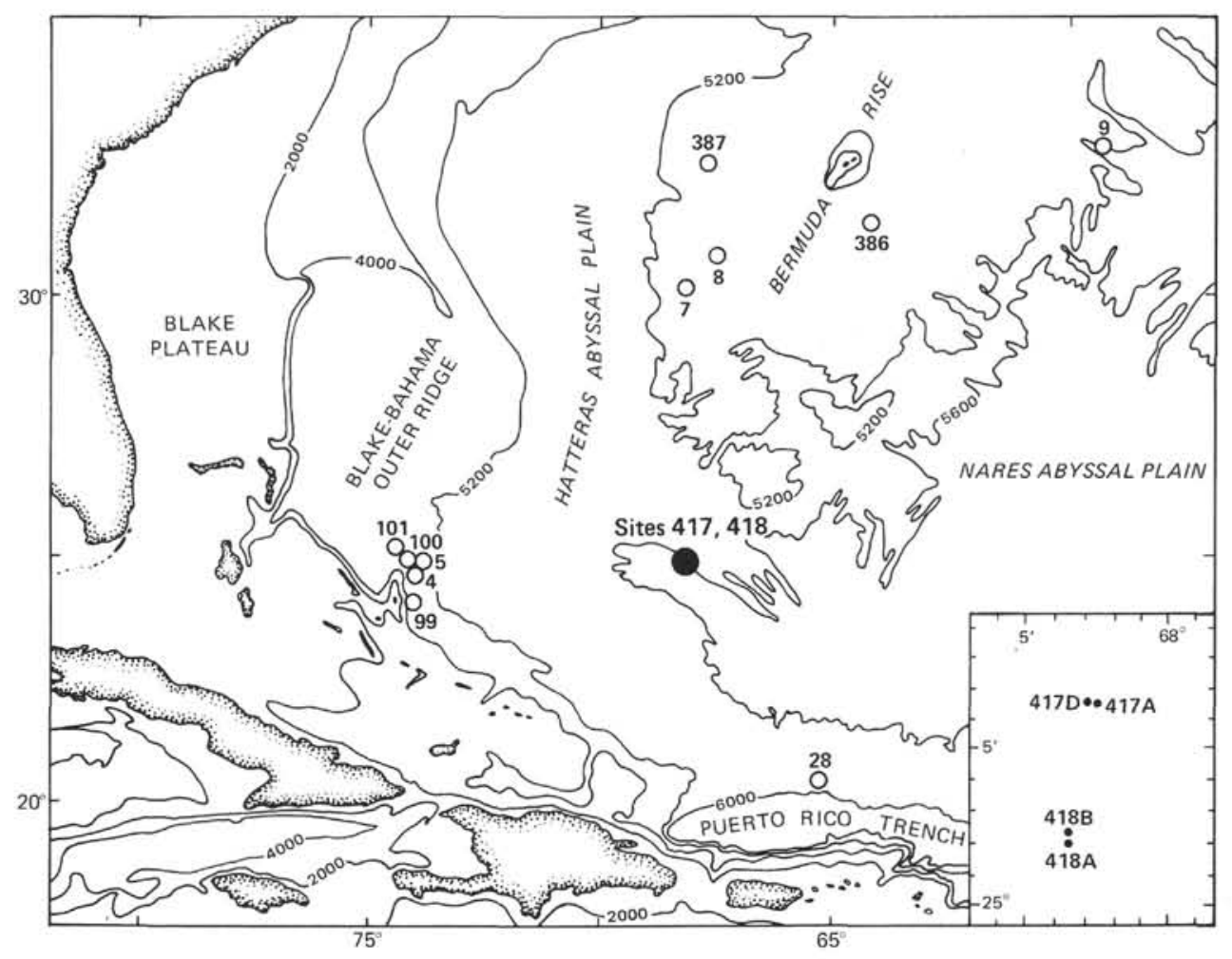

Figure 1. Location of Sites 417 and 418, Legs 51 through 53.

the most diagnostic marker in the assemblage, ranges from within the upper Albian to within the lower Cenomanian. The other species, except for $H$. yezoana, have been reported much more frequently from the Cenomanian than from the Albian. Schackoina cenomana, as far as we are aware, has not been reported from strata lower than uppermost Albian. We have assigned this assemblage to the uppermost Albian to lower Cenomanian (undifferentiated), since we cannot refine its stratigraphic position sufficiently to place it in either the Albian or the Cenomanian. Sample 417D-17-2, 104-106 cm, situated approximately 2.5 meters below these rich faunas, contains a sparse assemblage consisting of $H$. planispira, $H$. delrioensis, $H$. amabilis, and $C$. moremani. We have assigned this sample to the same interval: uppermost Albian to lower Cenomanian.

The next sample downhole in which planktonic foraminifers occur, Sample 417D-19, CC, contains rare specimens of Hedbergella trocoidea (Gandolfi) and rare small hedbergellids of unknown affinities which we have tentatively place in Hedbergella $\mathrm{cf}$. $H$. sigali Moullade. Two samples collected from the interval $18-22 \mathrm{~cm}$ in Section 417D-20-2 contain numerous $H$. trocoidea and rare specimens of Globigerinelloides maridalensis (Bolli) and "Globigerinelloides" gyroidinaeformis Moullade. In addition, two specimens of Globigerinelloides sp. and one specimen of Ticinella breggiensis (Gandolfi) were recovered in Sample 417D-20-2, 20-22 cm.

Valid records of the occurrence of $H$. trocoidea indicate that it ranges from upper Aptian to approximately upper Albian. Reports of its occurrence in the Cenomanian refer to other species. Globigerinelloides maridalensis and " $G$." gyroidinaeformis are less well known than $H$. trocoidea, and their stratigraphic ranges are not yet well established. Globigerinelloides maridalensis apparently ranges from lower Aptian to at least lower Albian. Krasheninnikov (1974, p. 666, pl. 2, fig. 14, 15) has reported the occurrence of $G$. aff. $G$. maridalensis in the eastern Indian Ocean which appears to belong to this species. The stratigraphic position of the sample containing his specimens is probably middle Albian. "Globigerinelloides" gyroidinaeformis occurs throughout the Albian, especially in the lower and middle Albian.

The overlapping ranges of $H$. trocoidea, G. maridalensis, and "G." gyroidinaeformis suggest that samples in Section 417D-20-2 belong to the lower to middle Albian (undifferentiated). We have also included the sparse assemblage in Sample 417D-19, CC in this interval because of the presence of $H$. trocoidea. In all three holes in which Cretaceous planktonic foraminifers were recovered (Holes 417D, 418A, and 418B), H. trocoidea is the dominant and most characteristic species recovered from this interval. The occurrence of Ticinella breggiensis in Sample 417D-20-2, $20-22 \mathrm{~cm}$ seems anomalous since that species has previously been reported principally from the upper Albian and the lower part of the lower Cenomanian.

Basaltic basement at Hole 417D was encountered in Section 417D-21-4. Sediments in the upper part of that section and in overlying Section 417D-21-3 yielded lower Aptian and possible lower Aptian planktonic foraminifer assemblages.

Two samples collected from the $6-12 \mathrm{~cm}$ interval of Section 417D-21-3 contain one specimen of $G$. maridalensis and five specimens of $H$. cf. $H$. sigali. The exact stratigraphic position of this interval is unknown, but the absence 
TABLE 1

Planktonic Foraminifers From Holes 417, 417A, 417B, and 417D

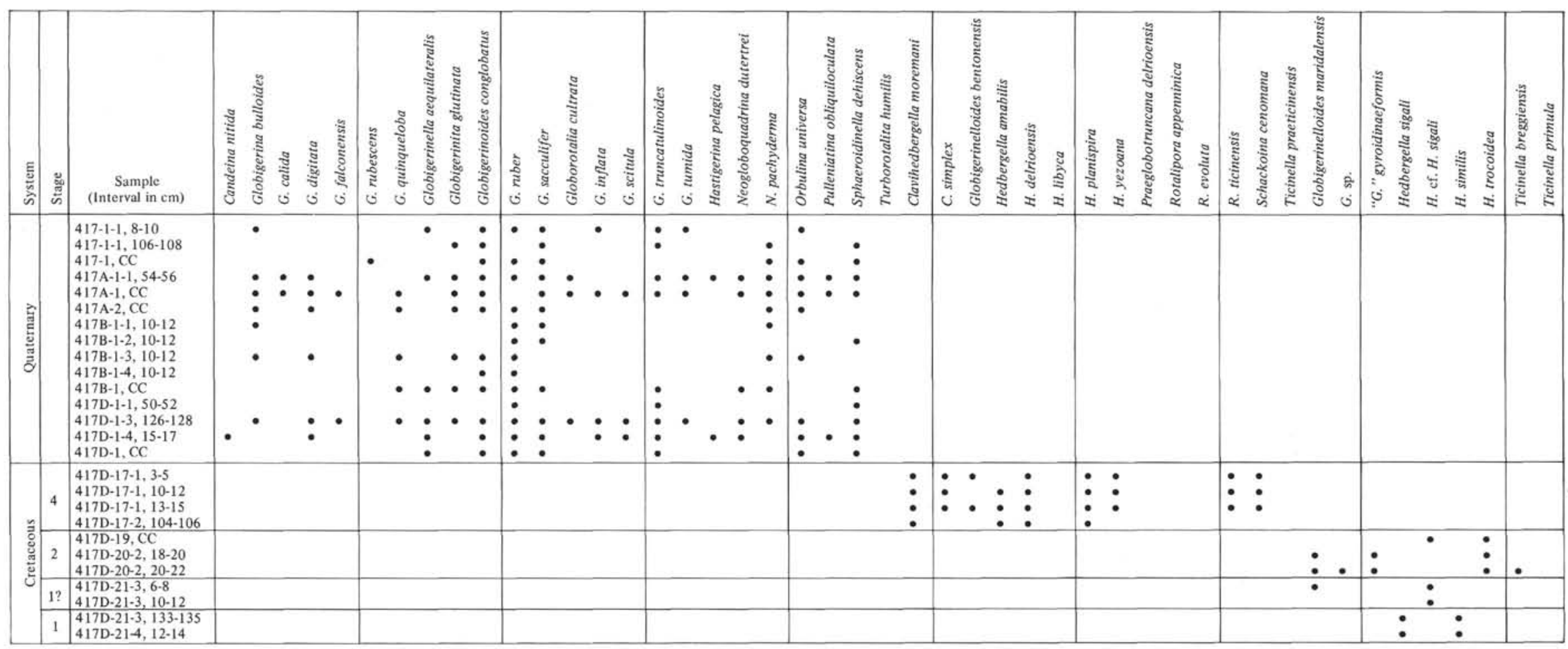

${ }^{2}$ Quaternary samples from these holes are shown together for convenience only and do not indicate relative stratigraphic position. Cretaceous stage assignments are: lower Aptian (1), lower to middle Albian (2), and uppermost Albian to lower Cenomanian (4). 


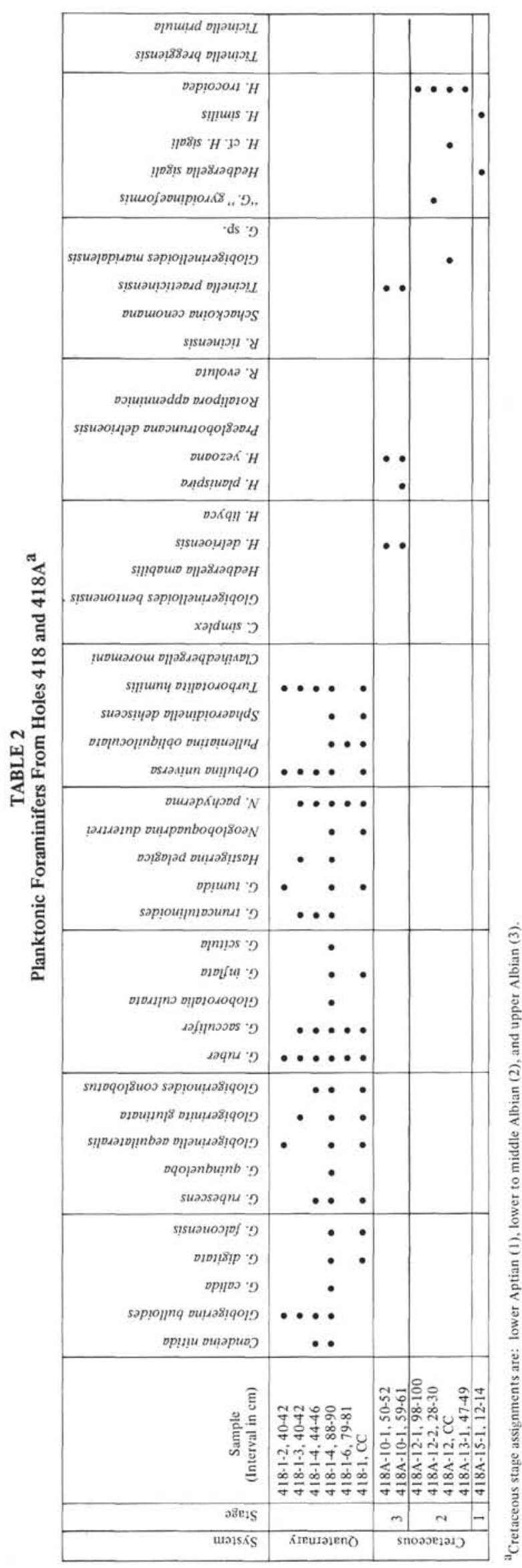

of $H$. trocoidea, which is the dominant species in lower to middle Albian sediments at Sites 417 and 418, suggests that this interval is somewhat older than Albian. This meager fauna is, however, different from the lower Aptian faunas in this hole and in Hole 418A.

Samples 417D-21-3, 133-135 cm and 417D-21-4, 12-14 $\mathrm{cm}$ contain Hedbergella sigali Moullade and Hedbergella similis Longoria and are assigned to the lower Aptian.

\section{Holes 418 and 418A (Table 2)}

At Hole 418 , we collected a surficial punch core in 5511 meters of water. About 6 meters of brown pelagic clay recovered from this hole yielded Quaternary assemblages in various states of preservation. The fauna in Sample 418-1$4,88-90 \mathrm{~cm}$ is the best-preserved assemblage in this core. It consists of 24 extant species, including the Quaternary marker Globorotalia truncatulinoides.

Hole $418 \mathrm{~A}$, a deep penetration attempt, is located near Hole 418. The hole was washed to a depth of 111 meters, then cored almost continuously to basaltic basement. Fifteen cores were taken in the 324-meter sedimentary section. Planktonic foraminifers were recovered only from Cretaceous sediments in Cores 418A-10,12, 13, and 15. Cores $418 \mathrm{~A}-1$ through 9 are barren of diagnostic fossils, except for middle Eocene radiolarians in Cores 418A-6 and 7.

Two samples from the 50-61 cm interval in Section 418A-10-1, contain sparse planktonic foraminifer assemblages consisting of Hedbergella delrioensis, H. planispira, H. yezoana, and Ticinella praeticinensis Sigal. The absence of Rotalipora ticinensis and the presence of $T$. praeticinensis suggest that this assemblage is older than assemblages in Holes 417D and 418B which we have assigned to the uppermost Albian to lower Cenomanian. The sediments in Section 418A-10-1 are here assigned to the upper Albian. An equivalent but more diverse fauna in Hole $418 \mathrm{~B}$ contains Clavihedbergella moremani and Hedbergella amabilis, which are not known to occur below the upper Albian.

Core 418A-12 and Section 1 of Core 418A-13 contain sparse assemblages dominated by Hedbergella trocoidea. One sample in Core 418A-12 bears rare specimens of "Globigerinelloides" gyroidinaeformis, and another contains rare Globigerinelloides maridalensis and Hedbergella cf. $H$. sigali in addition to $H$. trocoidea. These sediments are assigned to the lower to middle Albian interval and are equivalent to those in Sample 417D-19, CC and Section 417D-20-2.

Sample 418A-15-1, 12-14 cm, collected just above basaltic basement, contains numerous specimens of Hedbergella sigali and Hedbergella similis. This assemblage is equivalent to the fauna immediately above basement in Hole 417D and is assigned to the lower Aptian.

\section{Hole 418B (Table 3)}

Hole 418B was a deep-penetration attempt located near Holes 418 and $418 \mathrm{~A}$. Coring was continuous to acoustic basement, and 34 cores were taken in the 319.5 -meter sedimentary section. The water depth at Hole 418B is 5514 meters.

Cores 1 through 26 consist of brown pelagic clay and zeolitic clay. Cores 27 through 34 are composed principally of nannofossil chalk, "radiolarian sandstone," and vari- 


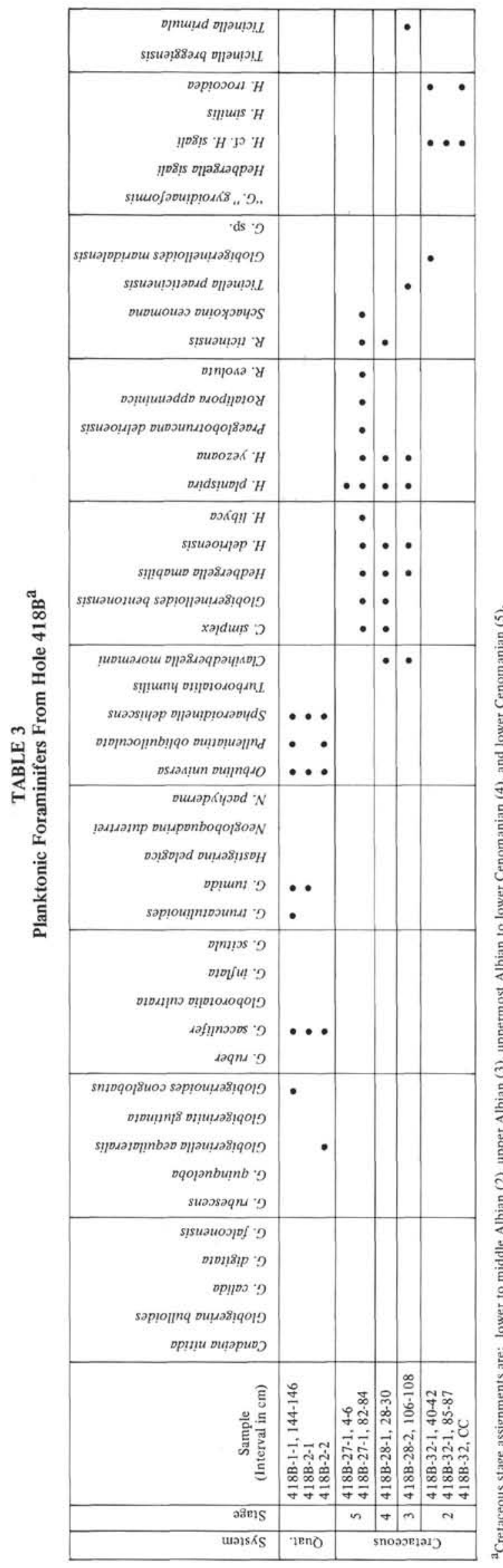

ously colored claystone. Age-diagnostic fossils are absent from the upper 26 cores, except for Quaternary planktonic foraminifers in Cores 418B-1 and 2, Paleogene orosphaerid radiolarian fragments in Core 418B-10, middle Eocene radiolarians in Core 418B-19, and Cenomanian calcareous nannofossils in Core 418B-26.

The planktonic foraminifer assemblage in Core 418B-1 is represented by a few solution-resistant species. The occurrence of Globorotalia truncatulinoides in this core indicates that these sediments are Quaternary. Core 418B-2 contains similar, but more strongly dissolved faunas.

Cretaceous planktonic foraminifers recovered from Section 418B-27-1 constitute the youngest Cretaceous assemblage recovered during Legs 51, 52, and 53. The occurrence of Rotalipora evoluta Sigal places these sediments in the lower Cenomanian. Other species comprising the fauna are Clavihedbergella simplex, Globigerinelloides bentonensis, Hedbergella libyca Barr, H. amabilis, H. delrioensis, $H$. planispira, Praeglobotruncana delrioensis (Plummer), Rotalipora appenninica (Renz), R. ticinensis, and Schackoina cenomana.

Section 1 of Core 418B-28 contains a fauna dominated by $H$. planispira and characterized by numerous specimens of Rotalipora ticinensis. This assemblage is essentially identical to the fauna in Sections 1 and 2 of Core 417D-17.

Section 2 of Core 418B-28 yielded the upper Albian Ticinella praeticinensis fauna which also occurs in Section 418A-10-1. In addition to $T$. praeticinensis, we recovered specimens of Ticinella primula Luterbacher, Clavihedbergella moremani, Hedbergella amabilis, $H$. delrioensis, and $H$. yezoana.

Samples collected from Core 418B-32 yielded specimens of Hedbergella trocoidea, H. cf. H. sigali, and Globigerinelloides maridalensis. This core contains the same faunas as those in Cores 12 and 13 of Hole 418A and Cores 19 and 20 of Hole 417D and is assigned to the lower to middle Albian interval.

Planktonic foraminifers are absent in samples from Cores $418 \mathrm{~B}-33,34$, and 35 directly above basaltic basement in Hole 418B.

\section{CORRELATION}

\section{Summary of Correlations at Sites 417 and 418}

Quaternary planktonic foraminifer assemblages occur in all cores recovered near the surface at Sites 417 and 418 . Many faunas show signs of strong dissolution, whereas others are well preserved, diverse, and contain abundant foraminifers. The occurrence of planktonic foraminifers in sediments deposited far below the CCD is difficult to explain. We believe that at least some of the assemblages were transported to this area by turbidity currents and were subsequently preserved by rapid burial. Our richest and most diverse faunas, for example, were collected from thin layers of white, foraminifer-bearing nannofossil ooze which occasionally occur in the brown pelagic clay that constitutes the upper sedimentary section. The ooze layers are completely unlike the surrounding sediments, which suggests that they may have originated outside the area. Furthermore, studies of Quaternary calcareous nannofossils from Sites 417 and 418 by Gartner (this volume) and Siesser (this volume) have 
revealed mixing in the nannofossil floras. Transport by turbidity currents is one mechanism which could have caused such mixing.

We recognized five distinct planktonic foraminifer assemblages in Cretaceous sediments from Holes 417D, $418 \mathrm{~A}$, and $418 \mathrm{~B}$. Each of these faunas is characterized by one species that is numerous only in that assemblage. In four of the faunas, the characteristic species is confined to the assemblage. Correlations among these faunas are shown in Figure 2.

The youngest Cretaceous assemblage recovered during Legs 51,52 , and 53 is early Cenomanian. It occurs only in Sample 418B-27-1, $82-84 \mathrm{~cm}$ and is characterized by Rotalipora evoluta. This species and Hedbergella libyca, Praeglobotruncana delrioensis, and Rotalipora appenninica are confined to this sample. The assemblage also contains longer ranging species that occur in sediments as old as late Albian at Sites 417 and 418 .

An older assemblage, assigned to the uppermost Albian to lower Cenomanian, occurs in Sections 417D-17-1, 417 D-17-2, and 418B-28-1. It is characterized by numerous specimens of Rotalipora ticinensis and an abundance of Hedgergella planispira and $H$. delrioensis.

Stratigraphically below the uppermost Albian to lower Cenomanian assemblage is an upper Albian fauna that contains several of the same species. The occurrence of numerous Ticinella praeticinensis and the absence of Rotalipora ticinensis, however, distinguish this assemblage from the younger one. The upper Albian fauna occurs in Sections 418A-10-1 and 418B-28-2.

All three Cretaceous sections recovered at Sites 417 and 418 contain a planktonic foraminifer assemblage consisting of numerous Hedbergella trocoidea and rare specimens of Globigerinelloides maridalensis, "Globigerinelloides" gyroidinaeformis, and Hedbergella cf. H. sigali. This assemblage is assigned to the lower to middle Albian and occurs in Sample 417D-19, CC and Cores 417D-20, 418A$12,418 \mathrm{~A}-13$, and 418B-32. Benthic foraminifers, which are virtually absent from most of the sediments recovered in Holes 417D, 418A, and 418B, are numerous in this interval. In most samples, they are more abundant than the planktonic foraminifers.

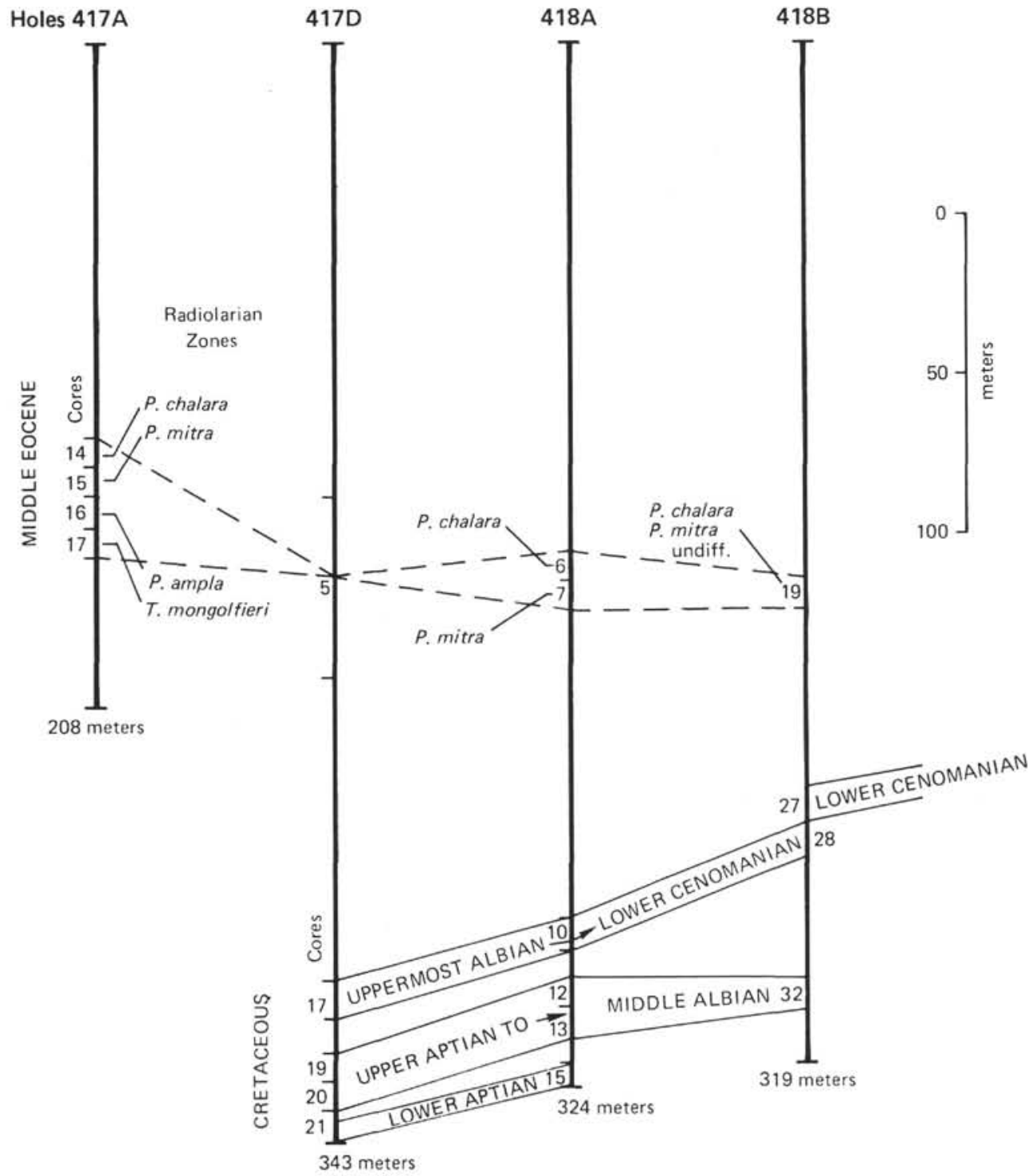

Figure 2. Correlation of Holes 417A, 417D, 418A, and 418B. 
The oldest assemblage in our material consists of only two species, Hedbergella sigali and Hedbergella similis, and is assigned to the lower Aptian.

\section{Correlations to Other DSDP Holes}

Previous investigations of Lower Cretaceous planktonic foraminifers from nearby DSDP holes include Luterbacher (1972), Pflaumann and Krasheninnikov (1978), and Gradstein (1978). Precise comparison of these investigations with ours is difficult because taxonomic concepts and biostratigraphic interpretations differ among authors. We believe, however, that our results compare favorably only with those of Pflaumann and Krasheninnikov (1978), and that Luterbacher (1972) and Gradstein (1978) recovered assemblages slightly different from ours.

Luterbacher (1972) reported the occurrence of Rotalipora apenninica apenninica, Praeglobotruncana delrioensis, Hedbergella amabilis, $H$. trocoidea, and Schackoina cenomana bicornis from the upper Albian of Hole 101A (see Figure 1 for location). He also recorded $R$. apenninica apenninica, $P$. delrioensis, and Planomalina buxtorfi from the upper Albian or lower Cenomanian of Hole 105. Both assemblages are similar to our lower Cenomanian fauna, but include species suggesting somewhat lower stratigraphic positions.

Pflaumann and Krasheninnikov (1978) reported the occurrence of rich assemblages from Lower Cretaceous sediments of the northwestern Africa offshore area. (Our faunas are much less diverse, but nevertheless appear to be correlative.) Among their many faunas are the following, which correspond closely to our four oldest assemblages: an uppermost Albian to basal Cenomanian fauna from Holes 367 (Cores 19 through 21) and 370 (Cores 20 through 26) that contains Rotalipora ticinensis and many other species recovered in assemblages we assigned to the uppermost Albian to lower Cenomanian; a middle to upper Albian fauna from Hole 369A (Cores 41 through 43) that lacks $R$. ticinensis, but contains Ticinella praeticinensis, Ticinella primula, and other species we found in our upper Albian assemblages; a lower Albian fauna from Holes 367 (Core 22) and 370 (Core 30) which contains Hedbergella trocoidea and "Globigerinelloides" gyroidinaeformis, as in our lower to middle Albian assemblages; and a lower Aptian fauna from Holes 369A (Core 47) and 370 (Cores 31 through 34) which includes Hedbergella sigali and Hedbergella similis and correlates with our lower Aptian assemblages.

Gradstein (1978) recovered faunas from Blake Nose, north of the Bahama Islands, which include $H$. delrioensis, $H$. planispira, $H$. spp., Ticinella primula, and several species of benthic foraminifers. He assigns these faunas to the middle Albian Ticinella primula Zone of van Hinte (1976). These faunas are similar to our upper Albian assemblages, but differ in having numerous species of benthic foraminifers and in lacking Ticinella praeticinensis. Gradstein also recovered middle and upper Albian faunas from Hole 392A. These contain the same species we found in our Albian samples, but the species occur in combinations that we did not see in our samples. We believe, therefore, that our assemblages are not precisely correlative to his.

\section{SYSTEMATIC PALEONTOLOGY}

The following section includes an alphabetical listing of the Quaternary planktonic foraminifers recovered during Legs 51,52 , and 53 and a more detailed discussion of the Cretaceous foraminifers recovered during these legs.

\section{Quaternary Species}

Candeina nitida d'Orbigny, 1839, in de la Sagra, Hist. Phys. Pol. Nat. Cuba, "Foraminiferes," p. 108, pl. 2, fig. 27, 28.

Globigerina bulloides d'Orbigny, 1826, Ann. Sci. Nat., ser. 1, v. 7, p. 277 , mod. $17,76$.

Globigerina calida Parker, 1962, Micropaleontology, v. 8, p. 221, pl. 1, fig. $9-13,15$.

Globigerina digitata Brady, 1879, Quart. J. Micr. Sci, new ser., v. 19, p. 286.

Globigerina falconensis Blow, 1959, Am. Paleontol. Bull., v. 39, p. 177, pl. 9 , fig. $40,41$.

Globigerina quinqueloba Natland, 1938, Scripps Inst. Oceanogr. Bull. Tech. Ser., v. 4, p. 149, pl. 6, fig. 18-21.

Globigerina rubescens Hofker, 1956, Spolia Zool. Mus. Hauniensis, v. 15 , p. 234 , pl. 35 , fig. $18-21$.

Globigerinella aequilateralis (Brady).

Globigerina aequilateralis Brady, 1879, Quart. J. Micr. Sci., new ser., v. 19 , p. 285.

Globigerinita glutinata (Egger).

Globigerina glutinata Egger, 1893, Abh. K. Bayer Akad. Wiss. Munchen, CLII, v. 18, p. 371, pl. 13, fig. 19-21.

Globigerinoides conglobatus (Brady).

Globigerina conglobata Brady, 1879, Quart, J. Micr. Sci., new ser., v. 19 , p. 286.

Globigerinoides ruber (d'Orbigny).

Globigerina rubra d'Orbigny, 1839, in de la Sagra, Hist. Phys. Pol. Nat. Cuba, "Foraminiferes," p. 82, pl. 4, fig. 12-14.

Globigerinoides sacculifer (Brady).

Globigerina sacculifera Brady, 1877, Geol. Mag., new ser., v. 4, p. 535.

Globorotalia cultrata (d'Orbigny).

Rotalina (Rotalina) cultrata d'Orbigny, 1839, in de la Sagra, Hist. Phys. Pol. Nat. Cuba, "Foraminiferes," p. 76, pl. 5, fig. 7-9.

Globorotalia inflata (d'Orbigny).

Globigerina inflata d'Orbigny, 1839, in Barker-Webb and Berthelot, Hist. Nat. Isles Canaries, “Foraminiferes," v. 2, p. 134, pl. 2, fig. 7-9.

Globorotalia scitula (Brady).

Pulvinulina scitula Brady, 1882, Roy. Soc. Edinburgh, Proc., v. 11 (1880-1882), no. 111 , p. 716.

Globorotalia truncatulinoides (d'Orbigny).

Rotalina truncatulinoides d'Orbigny, 1839, in Barker-Webb and Berthelot, Hist. Nat. Isles Canaries, "Foraminiferes," v. 2, p. 132, pl. 2, fig. 25-27.

Globorotalia tumida (Brady).

Pulvinulina menardii (d'Orbigny) var. tumida Brady, 1877, Geol. Mag., new ser., v. 4 , p. 535 .

Hastigerina pelagica (d'Orbigny).

Nonionina pelagica d'Orbigny, 1839, Voy. Am. Merid., "Foraminiferes," v. 5 , p. 27 , pl. 3 , fig. 13,14 .

Neogloboquadrina dutertrei (d'Orbigny).

Globigerina dutertrei d'Orbigny, 1839, in de la Sagra, Hist. Phys. Pol. Nat. Cuba, "Foraminiferes," p. 84, pl. 4, fig. 19-21.

Neogloboquadrina pachyderma (Ehrenberg).

Aristerospira pachyderma Ehrenberg, 1861, K. Preuss. Akad. Wiss. Berlin, Monatsber., p. 303.

Orbulina universa d'Orbigny, in de la Sagra, Hist. Phys. Pol. Nat. Cuba, "Foraminiferes," p. 3, pl. 1, fig. 1.

Pulleniatina obliquiloculata (Parker and Jones).

Pullenia obliquiloculata Parker and Jones, 1862, in Carpenter, Introduction to the Study of Foraminifera, p. 183.

Sphaeroidinella dehiscens (Parker and Jones).

Sphaeroidina bulloides d'Orbigny var. dehiscens Parker and Jones, 1865, Phil. Trans. Roy. Soc. London, v. 155, p. 369, pl. 19, fig. 5.

Turborotalita humilis (Brady).

Truncatulina humilis Brady, 1884, Rept. Voy. Challenger, Zool., v. 9, p. 665 , pl. 94 , fig. 7. 


\section{Cretaceous Species}

Genus GLOBIGERINELLOIDES Cushman and Ten Dam, 1948 Globigerinelloides bentonensis (Morrow)

(Plate 1, Figures 1-3)

Anomalina bentonensis Morrow, 1934, J. Paleontol., v. 8, p. 201, pl. 30, fig. $4 a$, b.

Globigerinelloides bentonensis (Morrow). Loeblich and Tappan, 1961, Micropaleontology, v. 7, p. 267, pl. 2, fig. 8a-10b.

This species is a minor component of faunas recovered from Cores 417D-17 and 418B-28 (uppermost Albian to lower Cenomanian) and from Core 418B-27 (lower Cenomanian).

Most records of $G$. bentonensis are from the Cenomanian, but this species has also been reported from the Albian by Risch (1971, p. 55); Krasheninnikov (1974, p. 666); Sliter (1976, p. 541); and Pflaumann and Krasheninnikov (1978, p. 544).

\section{"Globigerinelloides" gyroidinaeformis Moullade} (Plate 1, Figures 4, 5)

"Globigerinelloides" gyroidinaeformis Moullade, 1966, Doc. Lab. Geol. Fac. Sci., Lyon, v. 15, p. 128, pl. 9, fig. 16-22.

This species occurs rarely in Section 417D-20-2 and in the upper part of Section 418A-12-2 (lower to middle Albian).

The holotype of " G." gyroidinaeformis is from the lower middle Albian Stage of France (Moullade, 1966, p. 128). This species has also been recorded from the lower Albian to lower middle Albian of the Bavarian Alps (Risch, 1971, p. 56); the upper Albian of the eastern Indian Ocean (Krasheninnikov, 1974, p. 666; see also Scheibnerová, 1974,p. 77 and pl. 6 and 7); the lower Albian of the eastern Falkland Plateau (Sliter, 1976, p. 541); and the lower Albian of the Cape Verde Basin and the deep basin off Morocco (Pflaumann and Krasheninnikov, 1978, p. 548).

"Globigerinelloides" gyroidinaeformis is characterized by its pseudoplanispiral coiling, rapid enlargement of chambers, and its peculiar test wall structure. Although it superficially resembles species of Globigerinelloides, it may actually be a benthic foraminifer. Risch $(1971$, p. 56$)$ and Sliter (1976, p. 541) have previously suggested possible benthic foraminiferal affinities for this species, but no one has yet demonstrated such affinities with certainty. Scheibnerová $(1974$, p. 715; pl. 6, fig. 9-16; pl. 7, fig. 1-3) has illustrated specimens of ?Lingulogavelinella sp. from the upper Albian Stage of the eastern Indian Ocean which are remarkably similar to "G." gyroidinaeformis. Although his identification of these foraminifers at the generic level is uncertain, he apparently considers them to be benthic.

\section{Globigerinelloides maridalensis (Bolli)} (Plate 1, Figures 6-8)

Planomalina maridalensis Bolli, 1959, Bull. Am. Paleontol., p. 261, pl. 20, fig. 4-6.

Globigerinelloides maridalensis (Bolli). Longoria, 1974, Rev. Espanola Micropaleontol., num. extraord., p. 86, pl. 9, fig. 4-7, 10-13; pl. 27, fig. 18.

Specimens occur rarely in Sections 417D-20-2, 417D-21-3 (upper part), and 418B-32-1, and in Sample 418A-12,CC. All occurrences are in lower to middle Albian sediments.

The holotype of G. maridalensis was collected from the Biglobigerinella barri Zone (uppermost Aptian to lower Albian) of the Maridale Formation, Trinidad (Bolli, 1959, p. 261). Bolli (1959, chart 1) indicates that the species ranges throughout this zone. Longoria $(1974$, p. 88 ) has recorded this species from the lower to upper Aptian of northern Mexico and has noted its occurrence in the Aptian of France.

?Hastigerinoides alpina Sigal, from the upper Aptian of France (Sigal, 1959, p. 74), and Globigerinelloides aff. maridalensis (Bolli) of Krasheninnikov (1974, p. 666), from the eastern Indian Ocean, probably also belong to this species. The stratigraphic position of the sample in which Krasheninnikov's specimens occur is probably middle Albian (see Proto Decima, 1974, table 4, Sample 260-10,CC).

\section{Globigerinelloides sp.}

(Plate 1, Figure 9)

Two small speciments of Globigerinelloides sp. were recovered in Sample 417D-20-2, 20-22 cm (lower to middle Albian). They appear to be closely related to Globigerinelloides bentonensis (Morrow), but differ in lacking the coalesced relict apertural flaps and the heavily rugose earlier chambers typical of the well-preserved specimens of $G$. bentonensis from the Bermuda Rise.

Genus SCHACKOINA Thalmann, 1932

Schackoina cenomana (Schacko)

(Plate 1, Figures 10-13)

Siderolina cenomana Schacko, 1897, Ver. Freunde Naturg. Meckelnburg, Archiv., Jahrg. 50 (1896), p. 166, pl. 4, fig. 3-5.

Schackoina cenomana (Schacko). Glaessner, 1937, Moscow, Univ., Lab. Pal., Studies in Micropaleontology, v. 1, p. 44, 45.

This species occurs rarely in Section 417D-17-1 (uppermost Albian to lower Cenomanian) and in Section 418B-27-1 (lower Cenomanian).

Our specimens consistently have four chambers in the outer whorl. Tubulospines occur on all four chambers in some speciments, but more frequently they occur only on the last three. A few of the specimens are exceptionally well preserved, and have tubulospines that are set apart from the chambers by constrictions at the chamber tips.

\section{Genus HEDBERGELLA Brönnimann and Brown, 1958 \\ Hedbergella amabilis Loeblich and Tappan (Plate 2, Figures 1-3)}

Hedbergella amabilis Loeblich and Tappan, 1961, Micropaleontology, v. 7 , p. 274 , pl. 3 , fig. 1-10.

This species frequently occurs in Sample 418B-28-2, 106-108 cm (upper Albian); Core 417D-17 and Sample 418B-28-1, 28-30 cm (uppermost Albian to lower Cenomanian); and Core 418B-27 (lower Cenomanian).

Specimens from the Bermuda Rise intergrade morphologically with Hedbergella delrioensis (Carsey), indicating that the two species are closely related, as suggested by Pessagno (1967, p. 281).

Some workers consider $H$. amabilis to be a junior synonym of Hastigerinella simplicissima Magne and Sigal, but others consider $H$. simplicissima to be a junior synonym of Clavihedbergella simplex (Morrow). We have elected to use the well-established name "amabilis" for the present species until these problems can be resolved.

Recorded occurrences of $H$. amabilis indicate that this species ranges throughout the Cenomanian. Gradstein $(1978$, p. 668,669$)$ recently reported its occurrence in Albian sediments from the northwestern Atlantic Ocean.

\section{Hedbergella delrioensis (Carsey)}

(Plate 2, Figures 6-8)

Globigerina cretacea d'Orbigny var. delrioensis Carsey, 1926, Univ. Texas Bull. 2612, p. 43 .

Hedbergella delrioensis (Carsey). Loeblich and Tappan, 1961, Micropaleontology, v. 7, p. 275, pl. 2, fig. 11a-13c.

Hedbergella delrioensis occurs in Core 418A-10 and Sample 418B-28. 2, 106-108 cm (upper Albian); Core 417D-17 and Sample 418B-28-1, 28-30 cm (uppermost Albian to lower Cenomanian); and Core 418B-27 (lower Cenomanian). It is abundant in the uppermost Albian to lower Cenomanian interval, but is less numerous elsewhere.

\section{Hedbergella libyca Barr \\ (Plate 2, Figures 4, 5)}

Hedbergella libyca Barr, 1972, Micropaleontology, v. 18, p. 14, pl. 10, fig. 5a-c.

Hedbergella libyca is the most abundant species in Sample 418B-27-1, $82-84 \mathrm{~cm}$ (lower Cenomanian). In our material, it occurs only in that sample.

The holotype of this species was recovered from the lower Cenomanian part of the Hilal Shale in northeastern Libya (Barr, 1972, p. 14). The species is characterized by having a rugose surface on all but the last one or two chambers, and by having five to seven (usually six) chambers in the outer whorl, a moderately broad umbilicus, and well-developed portici. Saint-Marc (1973, p. 11) described a new species, Hedbergella costellata, from the middle Cenomanian of Lebanon which appears to be identical to $H$. libyca. The type descriptions and illustrations of the holotypes of these species do not differ significantly, except for the absence of portici from $H$. costellata. It is doubtful, however, that these delicate structures would be preserved on Saint-Marc's marginally preserved specimens. 
Saint-Marc (1973, pl. 1 and 2) illustrates more variability in this species than does Barr. Most of our specimens from Hole 418B are about the same size and shape as Barr's and Saint-Marc's holotypes, but we also recovered many large specimens (see Plate 2, Figures 4,5 ) which are essentially identical to Saint-Marc's paratype II. In the earlier stages of growth, the trochoid spire of these large specimens is flat and the increase in chamber size is rapid. As growth continues, the rate of increase of chamber size diminishes and the chambers begin to "turn under," resulting in a strongly convex spire.

Rugosity on specimens from Hole 418B varies from poorly developed to well developed. Most of our specimens are moderately to strongly rugose.

In addition to the Cenomanian occurrences from Libya (Barr, 1972), Lebanon (Saint-Marc, 1973), and Hole 418B on the Bermuda Rise, this species has also been reported from the Albian of the Walvis Ridge and Angola Basin (Caron, 1978, p. 658; sub Hedbergella costellata).

\section{Hedbergella planispira (Tappan)}

(Plate 3, Figures 1-4)

Globigerina planispira Tappan, 1940, J. Paleontol., v. 14, p. 12, pl. 19, fig. 12.

Hedbergella planispira (Tappan). Loeblich and Tappan, 1961, Micropaleontology, v. 7, p. 276, pl. 5, fig. 4-11c.

Hedbergella planispira occurs in Core 418A-10 and Sample 418B-28-2, 106-108 cm (upper Albian); Core 417D-17 and Sample 418B-28-2, 28-30 $\mathrm{cm}$ (uppermost Albian to lower Cenomanian); and Core 418B-27 (lower Cenomanian).

Our specimens are very small and remarkably uniform in their morphology.

\section{Hedbergella sigali Moullade}

(Plate 3, Figures 5, 6)

Hedbergella sigali Moullade, 1966, Doc. Lab. Geol. Fac. Sci., Lyon, v. 15 , p. 87 , pl. 7 , fig. $20-25$.

This species is abundant in the lower part of Section 417D-21-3; it also occurs in the upper part of Section 417D-21-4 and in Core 418A-15, but is much less numerous. All occurrences are from the lower Aptian.

Rare hedbergellids which may belong to this species are listed as Hedbergella $\mathrm{cf} . H$. sigali in Tables 1,2 , and 3 . These specimens occur at stratigraphic levels higher than $H$. sigali, and are slightly different in their morphology.

\section{Hedbergella similis Longoria}

(Plate 3, Figures 7-9)

Hedbergella similis Longoria, 1974, Rev. Espanola Micropaleontol., num. extraord., p. 68 , pl. 16 , fig. $10-12$; pl. 18 , fig. 12,13 ; pl. 23 , fig. 14-16.

Numerous specimens of $H$. similis occur in the lower part of Section 417D-21-3. Rare specimens are present in Sections 417D-21-4 and 418A15-1. All occurrences are from the lower Aptian.

Longoria (1974, p. 33) gives the range of $H$. similis as lower Aptian to basal upper Aptian. This species has also been reported from Trinidad (Bolli, 1959, sub Hastigerinella aff. subcretacea Tappan; see Longoria, 1974 , p. 68) and from the Aptian of the continental slope off northwestern Africa and the Angola Basin (Pflaumann and Krasheninnikov, 1978, p. 547)

\section{Hedbergella trocoidea (Gandolfi)}

(Plate 3, Figures 10-14)

Anomalina lorneiana d'Orbigny var. trocoidea Gandolfi, 1942, Riv. Ital. Paleontol., v. 4, suppl., mem. 4, p. 98, pl. 2, fig. 1a-c; pl. 4, fig. 2, 3 ; pl. 13, fig. 2a, b, 5a, b.

Hedbergella trocoidea (Gandolfi). Brönnimann and Brown, 1958, Washington Acad. Sci. J., v. 48 , p. 16, text-fig. 1a-c.

Hedbergella trocoidea occurs in Sample 417D-19,CC and in Cores 417D-20, 418A-12, and 418B-32. All occurrences are in lower to middle Albian samples.

Spire height and test size are highly variable in specimens of $H$. trocoidea from the Bermuda Rise. Specimens range in size from extremely small to extremely large, and the dorsal side of some specimens is nearly flat; in others it is strongly convex.

The stratigraphic range of this species is upper Aptian to approximately upper Albian. Planktonic foraminifer specialists have applied the name "trocoidea" to two or more superficially similar forms, and reports of the occurrence of $H$. trocoidea, especially in Cenomanian strata, probably refer to other species.

\section{Hedbergella yezoana Takayanagi and Iwamoto (Plate 4, Figures 1-3)}

Hedbergella trocoidea (Gandolfi) subsp. yezoana Takayanagi and Iwamoto, 1962, Pal. Soc. Japan, Trans. Proc., Tokyo, n.s., p. 191, pl. 28, fig. 1a-2c.

This species is present in Core 418A-10 and Sample 418B-28-2, 106$108 \mathrm{~cm}$ (upper Albian); Core 417D-17 and Sample 418B-28-1, 28-30 cm (uppermost Albian to lower Cenomanian); and Core 418B-27 (lower Cenomanian). It is abundant in Sample 417D-17-1, 13-15 cm, but is less numerous in the other samples in which it occurs.

The holotype of $H$. yezoana was recovered from the upper Albian part of the Middle Yezo Group in Japan (Takayanagi and Iwamoto, 1962, p. 191). Although this form was originally considered to be a subspecies of Hedbergella trocoidea (Gandolfi), we feel that it is sufficiently distinct from $H$, trocoidea to be considered a separate species.

Specimens from the Bermuda Rise are numerous, well preserved, and fairly uniform in their morphology. They are characterized by having six to seven chambers in the final whorl, a moderate to rapid increase in chamber size, and a slightly concave to flat spiral side. The specimens are strikingly similar to Ticinella primula Luterbacher, but lack secondary apertures in the umbilical region. Most of the mature specimens in our samples are very close in size and shape to the paratype illustrated by Takayanagi and Iwamoto (1962, pl. 28, fig. la-c), except that they have about one-half to one fewer chamber in the final whorl.

Uppermost Albian and Cenomanian planktonic foraminifers which have been assigned to Hedbergella trocoidea by some authors should be compared to the holotype of $H$. yezoana for possible synonymy (see Loeblich and Tappan, 1961, pl. 5, fig. 1, 2; Todd and Low, 1964, pl. 2, fig. 1a-2c; Marianos and Zingula, 1966, pl. 37, fig. 8a-c; Bakarat, et al., 1974, pl. 1, fig. 8a-c). Hedbergella sp. A of Playford, et al. (1975, fig. 2, no. 10-12) from northern Queensland, Australia, probably also belongs to this species.

Genus CLAVIHEDBERGELLA Banner and Blow, 1959

\section{Clavihedbergella moremani (Cushman)}

(Plate 4, Figures 4-7)

Hastigerinella moremani Cushman, 1931, Contrib. Cushman, Lab. Foram. Res., v. 7, p. 86, pl. 11, fig. 1 (non fig. 2, 3).

Clavihedbergella moremani (Cushman). Loeblich and Tappan, 1961, Micropaleontology, v. 7, p. 279, pl. 5, fig. 12-16.

This species occurs rarely in Sample 418B-28-2, 106-108 cm (upper Albian), and in Core 417D-17 and Sample 418B-28-1, 28-30 cm (uppermost Albian to lower Cenomanian).

Nearly all specimens of $C$. moremani in our samples have small tests with four chambers in the outer whorl. Large stellate specimens, such as those illustrated in Plate 4, Figures 6, 7, are rare. The trochoid spires of these large specimens are not readily discernible, making these forms difficult to distinguish from Hastigerinoides watersi (Cushman). Specimens closely resembling these large forms have been illustrated by Loeblich and Tappan (1961, pl. 5, fig. 16) from the Cenomanian/Turonian Britton Clay of Texas and by Todd and Low (1964, pl. 1, fig. 7; sub Schackoina pustulans Bolli) from Cenomanian rocks dredged from the northern slope of the Puerto Rico Trench.

Clavihedbergella moremani ranges from the uppermost Albian (see Pflaumann and Krasheninnikov, 1978, p. 547) to the Turonian (Pessagno, 1967, p 254). Most records of its occurrence are from the Cenomanian.

\section{Clavihedbergella simplex (Morrow)}

(Plate 4, Figures 8-10)

Hastigerinella simplex Morrow, 1934, J. Paleontol., v. 8, p. 198, pl. 30 , fig. $6 a, b$.

Clavihedbergella simplex (Morrow). Loeblich and Tappan, 1961, Micropaleontology, v. 7, p. 279, pl. 3, fig. 12a-14c (non pl. 3, fig. 11a-c).

Clavihedbergella simplex is a rare component of faunas in Cores 417D-17 and 418B-28 (uppermost Albian to lower Cenomanian) and Core 418B-27 (lower Cenomanian).

Specimens from the Bermuda Rise do not have the finely spinose test wall reported by other workers (Cushman, 1946, p. 148, Loeblich and 
Tappan, 1961, p. 279; cf. Douglas, 1969, p. 163). The wall is smooth and finely perforate, and is hispid only on the earlier chambers.

Pessagno (1967, p. 285) noted that $C$. simplex is transitional with Hedbergella amabilis Loeblich and Tappan and suggested that it evolved from $H$. amabilis. This transition has also been recorded by Eicher and Worstell (1970, p. 306) and Petters (1977, p. 178). Specimens from our samples, however, are easily distinguished from $H$. amabilis by being much smaller at the same stage of growth, by having a smoother test wall, and by having proportionally more elongate chambers. No transition between the species is evident in our material.

Clavihedbergella simplex has been recorded in the upper Cenomanian to Coniacian of the U. S. Gulf Coast and Mexico (Pessagno, 1967, p 254), California (Douglas, 1969, p. 164), and New Jersey (Petters, 1977, p. 169). It has also been reported from the Cenomanian of Cuba and North Africa (fide Pessagno, 1967, p. 286) and from the upper Cenomanian to Turonian of the central U.S.A. (Eicher and Worstell, 1970, p. 306).

\section{Genus PRAEGLOBOTRUNCANA Bermudez, 1952}

\section{Praeglobotruncana delrioensis (Plummer)}

(Plate 4, Figures 11, 12)

Globorotalia delrioensis Plummer. Univ. Texas Bull. 3101, p. 199, pl. 13, fig. 2a-c.

Praeglobotruncana delrioensis (Plummer). Bermudez, 1952, Venezuela, Minist. Minas y Hidrocarb., Bol. Geol., v. 2, p. 52, pl. 7, fig. 1.

Praeglobotruncana delrioensis occurs rarely in Sample 418B-27-1, $82-84 \mathrm{~cm}$ (lower Cenomanian). Specimens from this sample are characterized by having about five chambers in the outer whorl, a nearly equally biconvex test, and an acute periphery without a keel.

\section{Genus ROTALIPORA Brotzen, 1942}

\section{Rotalipora appenninica (Renz)}

Globotruncana appenninica Renz, 1936, Eclog. Geol.Helv., v. 29, p. 20, 135, text-fig. 2, 7a; pl. 6, fig. 1-11; pl. 7, fige 1; pl. 8, fig 4 .

Rotalipora apenninica (O. Renz). Sigal, 1952. XIX Congr. Geol. Internat., Monogr. Reg. ser. 1, Algerie, p. 24, text-fig. 23.

This species occurs only in Sample 418B-27-1, 82-84 cm (lower Cenomanian), where it is the most numerous of three species of Rotalipora.

\section{Rotalipora evoluta Sigal}

(Plate 5, Figures 1-3)

Rotalipora cushmani (Morrow) var, evoluta Sigal, 1948, Rev. Inst. Franc. Petrol., v. 3, p. 100, pl. 1, fig. 3; pl. 2, fig. 2.

Rotalipora evoluta Sigal. Loeblich and Tappan, 1961, Micropaleontology, v. 7 , p. 298 , pl. 7 , fig. 1-4.

Several specimens occur in Sample 418B-27-1, 82-84 cm (lower Cenomanian). They differ from specimens of Rotalipora appenninica in the same sample by having a more lax mode of coiling, a more rapid increase in chamber size, and a well-developed umbilical shoulder.

Valid reports of the occurrence of Rotalipora evoluta indicate that it is confined to the lower Cenomanian.

\section{Rotalipora ticinensis (Gandolfi)}

(Plate 5, Figures 4-7)

Globotruncana ticinensis Gandolfi, 1942, Riv. Ital. Paleontol,, v. 4. suppl., mem. 4 , p. 113, pl. 2, fig. 3a-c; pl. 4, fig. 10, 11-23; pl. 5, fig. 2,4 ; pl. 8 , fig. $4-7$; pl. 12 , fig. 1 ; pl. 13 , fig. 11 a,b, 12a,b; textfig. 39 .

Rotalipora ticinensis (Gandolfi). Caron and Luterbacher, 1969, Contrib. Cushman Found. Foram. Res. v. 20, p. 25, pl. 8, fig. 6a-c.

Numerous specimens of $R$. ticinensis occur in Cores 417D-17 and 418B-28 (uppermost Albian to lower Cenomanian). Three small, wellpreserved specimens were also recovered from Sample 418B-27-1, $82-84 \mathrm{~cm}$ (lower Cenomonian). Specimens from the Bermuda Rise are similar to the holotype in their morphology, but some are flatter dorsally. Rotalipora tehamaensis Marianos and Zingula, from the upper Albian of California (see Marianos and Zingula, p. 339, pl. 38, fig. 4 a-c), and specimens from the Cenomanian of the Blake Plateau identified by Loeblich and Tappan (1961, pl. 7, fig. 5, 6a-c) as Rotalipora greenhornensis (Morrow) seem to be morphologically very close to our specimens.
The holotype of $R$. ticinensis was collected from the lower part of the "Scaglia bianca" (Gandolfi, 1942), which Caron and Luterbacher (1969, p. 24) consider to be Albian. Subsequent records of its occurrence indicate that its range is upper Albian to lower Cenomanian.

\section{Genus TICINELLA Reichel, 1950}

Ticinella breggiensis (Gandolfi)

(Plate 6, Figures 1, 2)

Anomalina breggiensis Gandolfi, 1942, Riv. Ital. Paleontol., v. 4, suppl., mem. 4 , p. 102 , pl. 3 , fig. 6 a-c; pl. 5 , fig. 3 ; pl. 9 , fig. 1 ; pl. 13 , fig. 7,8 .

Ticinella breggiensis (Gandolfi). Longoria, 1974, Rev. Espanola Micropaleontol., num. extraord., p. 94, pl. 25, fig. 7, 14-16.

One specimen of $T$. breggiensis was recovered from Sample 417D-20-2, 20-22 cm (lower to middle Albian).

Most records of this species are from the upper Albian or lower Cenomanian. The sample from which our specimen was recovered is probably not higher than middle Albian since it contains several specimens of Globigerinelloides maridalensis (Bolli), which is not known to occur above the middle Albian.

\section{Ticinella praeticinensis Sigal}

(Plate 6, Figures 3-7)

Ticinella praeticinensis Sigal, 1966, Eclog. Geol. Helv., v. 59, p. 195, pl. 2, fig. 3-8, pl. 3, fig. 1-6.

This species occurs rarely in Cores 418A-10 and 418B-28 (upper Albian).

Specimens from the Bermuda Rise appear similar to those illustrated by Pflaumann and Krasheninnikov (1978, PI. 4, fig. 8, 9; sub Ticinella roberti) from the Albian of the northwestern Africa continental shelf, and by Risch (1971, pl. 5, fig. 16-18) from the upper Albian of the Bavarian Alps. Our specimens agree well with Sigal's types, except that most are slightly compressed. They are similar to Rotalipora praebalernaensis $\mathrm{Si}$ gal, but the spiral side is nearly flat, rather than strongly convex as in $R$. praebalernaensis

\section{Ticinella primula Luterbacher}

Ticinella primula Luterbacher, 1963, Eclog. Geol. Helv., v. 56, p. 1085, text-fig. 4 (three figures).

Numerous specimens of T. primula occur in Sample 418B-28-2, $106-108 \mathrm{~cm}$ (upper Albian). They are typical of the species, and the secondary apertures are readily visible.

This species differs from Hedbergella yezoana Takayanagi and Iwamoto in having secondary apertures in the umbilical region, but apparently no other significant differences exist. Caron (1971, p. 146; 1978, p. 659) has drawn attention to the frequent absence of secondary apertures in T. primula, and we feel that Takayanagi and Iwamoto (1962) may have described a specimen without secondary apertures as their new subspecies, Hedbergella trocoidea (Gandolfi) subsp. yezoana. The holotypes of $T$. primula and $H$. yezoana need to be compared for possible synonymy.

Recorded occurrences of $T$. primula indicate that it occurs only in the Albian and Vraconian.

\section{ACKNOWLEDGMENTS}

We wish to thank Dr. Eric Schabtach, University of Oregon, Department of Biology, for allowing us to use the AMR 1000 scanning electron microscope in his laboratory. Costs for SEM operation and photography were met by a grant from the Deep Sea Drilling Project.

\section{REFERENCES}

Bakarat, M. G., Sadek, A., and Arafa, A. A., 1974. Planktonic foraminiferal zonation of early Upper Cretaceous in Mersa Matruh Well No. 1, Western Desert, Egypt, Rev. Espanola Micropaleontol., v. 6, p. 111-125.

Barr, F. T., 1972. Cretaceous biostratigraphy and planktonic foraminifera of Libya, Micropaleontology, v. 18, p. 1-46.

Bolli, H. M., 1959. Planktonic foraminifera from the Cretaceous of Trinidad, B.W.I., Am. Paleontol. Bull., v. 39, p. 257-277. 
Caron, M., 1971. Quelques cas d'instabilite des caracteres generiques chez les foraminiferes planctoniques de l'Albien, Proc. Second Plankt. Conf., Roma, 1970, p. 145-157. 1978. Cretaceous planktonic foraminifers from DSDP Leg 40, southern Atlantic Ocean. In Bolli, H. M., Ryan, W. B. F., et al., Initial Reports of the Deep Sea Drilling Project, v. 40: Washington (U.S. Government Printing Office), p. 651-678.

Caron, M. and Luterbacher, H., 1969. On some type specimens of Cretaceous planktonic foraminifera, Contrib. Cushman Found. Foram. Res., v. 20, p. 23-29.

Cushman, J. A., 1946. Upper Cretaceous foraminifera of the Gulf Coastal region of the United States and adjacent areas, U.S. Geol. Surv. Prof. Paper 206, p. 1-241.

Douglas, R. G., 1969. Upper Cretaceous planktonic foraminifera in northern California. Part I - systematics, Micropaleontology, v. 15, p. 151-209.

Eicher, D. L. and Worstell, P., 1970. Cenomanian and Turonian foraminifera from the Great Plains, United States, Micropaleontology, v. 16, p. 269-324.

Gandolfi, R., 1942. Richerche micropaleontologiche e stratigrafiche sulla Scaglia e sul Flysch cretacici dei dintorni di Balerna (Canton Ticino), Riv. Ital. Paleontol., v. 4, suppl., mem. 4 , p. $1-160$.

Gradstein, F. M., 1978. Biostratigraphy of Lower Cretaceous Blake Nose and Blake-Bahama Basin foraminifers DSDP Leg 44, western North Atlantic Ocean. In Benson, W. E., Sheridan, R. E., et al., Initial Reports of the Deep Sea Drilling Project, v. 44: Washington (U.S. Government Printing Office), p. 663-701.

Krasheninnikov, V. A., 1974. Cretaceous and Paleogene planktonic foraminifera, Leg 27 of the Deep Sea Drilling Project. In Veevers, J. J., Heirtzler, J. R., et al., Initial Reports of the Deep Sea Drilling Project, v. 27: Washington (U.S. Government Printing Office), p. 663-671.

Loeblich, A. R., Jr., and Tappan, H., 1961. Cretaceous planktonic foraminifera: Part 1 - Cenomanian, Micropaleontology, v. 7 , p. $257-304$.

Longoria, J. F., 1974. Stratigraphic, morphologic and taxonomic studies of Aptian planktonic foraminifera, Rev. Espanola Micropaleontol., Num. extraord., p. 1-107.

Luterbacher, H., 1972. Foraminifera from the Lower Cretaceous and Upper Jurassic of the northwestern Atlantic. In Hollister, C. D., Ewing, J. I., et al., Initial Reports of the Deep Sea Drilling Project, v. 11: Washington (U.S. Government Printing Office), p. 561-593.

Marianos, A. W. and Zingula, R. P., 1966. Cretaceous planktonic foraminifers from Dry Creek, Tehama County, California, J. Paleontol., v. 40, p. 328-342.
Moullade, M., 1966. Etude stratigraphique et micropaleontogique du Cretace inferieur de la "fossa vocontienne", Doc. Lab. Geol. Fac. Sci., Lyon, v. 15, p. 1-369.

Pessagno, E. A., 1967. Upper Cretaceous planktonic foraminifera from the western Gulf Coastal Plain, Paleontogr. Americana, v. 5 , p. $245-445$.

Petters, S. W., 1977. Upper Cretaceous planktonic foraminifera from the subsurface of the Atlantic Coastal Plain of New Jersey, J. Foram. Res., v. 7, p. 165-187.

Pflaumann, U. and Krasheninnikov, V. A., 1978. Early Cretaceous planktonic foraminifers from eastern North Atlantic, DSDP Leg 41. In Lancelot, Y., Seibold, E., et al., Initial Reports of the Deep Sea Drilling Project, v. 41: Washington (U.S. Government Printing Office), p. 539-564.

Playford, G., Haig, D. W., and Dettmann, M. E., 1975. A midCretaceous microfossil assemblage from the Great Artesian Basin, northwestern Queensland, N. Jb. Geol. Palaontol. Abh., v. 149 , p. $333-362$.

Proto Decima, F., 1974. Leg 27 calcareous nannoplankton. In Veevers, J. J., Heirtzler, J. R., et al., Initial Reports of the Deep Sea Drilling Project, v. 27: Washington (U.S. Government Printing Office), p. 589-621.

Risch, H., 1971. Stratigraphie der hoheren Untekreide der bayrischen Kalkalpen mit Hilfe von Mikrofossilien, Paleontolographica, Abt. A, v. 138, p. 1-80.

Saint-Marc, P., 1973. Presence de Hedbergella a "costellae" dans le Cenomanien moyen du Liban, J. Foram. Res. v. 3, p. 7-12.

Scheibnerová, V., 1974. Aptian-Albian benthonic foraminifera from DSDP Leg 27, Sites 259, 260, and 263, eastern Indian Ocean. In Veevers, J. J., Heirtzler, J. R., et al., Initial Reports of the Deep Sea Drilling Project, v. 27: Washington (U.S. Government Printing Office), p. 697-741.

Sigal, J., 1959. Notes micropaleontologiques Alpines. Les generes Schackoina et Leupoldina dans le Gargasien Vocotien. Etude de morphogenese, Rev. Micropaleontol., v. 2, p. 68-79.

Sliter, W. V., 1976. Cretaceous foraminifers from the southwestern Atlantic Ocean, Leg 36, Deep Sea Drilling Project. In Barker, P. F., Dalziel, I. W. D., et al., Initial Reports of the Deep Sea Drilling Project, v. 36: Washington (U.S. Government Printing Office), p. 519-573.

Takayanagi, Y. and Iwamoto, H., 1962. Cretaceous planktonic foraminifera from the Middle Yezo Group of the Ikushumbetsu, Miruto, and Hatonosu areas, Hokkaido, Pal. Soc. Japan, Trans. Proc., Tokyo, 1962, n.s., p. 183-196.

Todd, R. and Low, D., 1964. Cenomanian (Cretaceous) foraminifera from the Puerto Rico Trench, Deep-Sea Res., v. 11, p. 395-414.

van Hinte, J. E., 1976. A Cretaceous time scale, Am. Assoc. Petrol. Geol. Bull., v. 60 , p. 498-516. 


\section{PLATE 1}

Figures 1-3 Globigerinelloides bentonensis (Morrow).

1. Side view, $\times 140$. Sample 417D-17-1, 3-5 cm, uppermost Albian to lower Cenomanian.

2. Side view, $\times 140$. Sample 417D-17-1, 13-15 cm, uppermost Albian to lower Cenomanian.

3. Edge view, $\times 140$. Sample 417D-17-1, 13-15 $\mathrm{cm}$, uppermost Albian to lower Cenomanian.

Figures 4, 5 "Globigerinelloides" gyroidinaeformis Moullade. Sample 417D-20-2, 20-22 cm, lower to middle Albian.

4. Side view, $\times 180$.

5. Edge view, $\times 170$.

Figures 6-8 Globigerinelloides maridalensis (Bolli).

Sample 417D-20-2, 20-22 cm, lower to middle Albian.

6. Side view, $\times 200$.

7. Side view, $\times 200$.

8. Side view, $\times 200$.

Figure 9 Globigerinelloides sp.

Sample 417D-20-2, $20-22 \mathrm{~cm}$, lower to middle Albian. Side view, $\times 170$.

Figures 10-13 Schackoina cenomana (Schacko).

10. Side view, $\times 140$. Sample 418B-27-1, $82-84 \mathrm{~cm}$, lower Cenomanian.

11. Side view, $\times 150$. Sample 418B-27-1, $82-84 \mathrm{~cm}$, lower Cenomanian.

12. Side view, $\times 100$. Sample 418B-27-1, $82-84 \mathrm{~cm}$, lower Cenomanian.

13. Side view, $\times 170$. Sample 417D-17-1, 10-12 cm, uppermost Albian to lower Cenomanian. 


\section{PLATE 1}
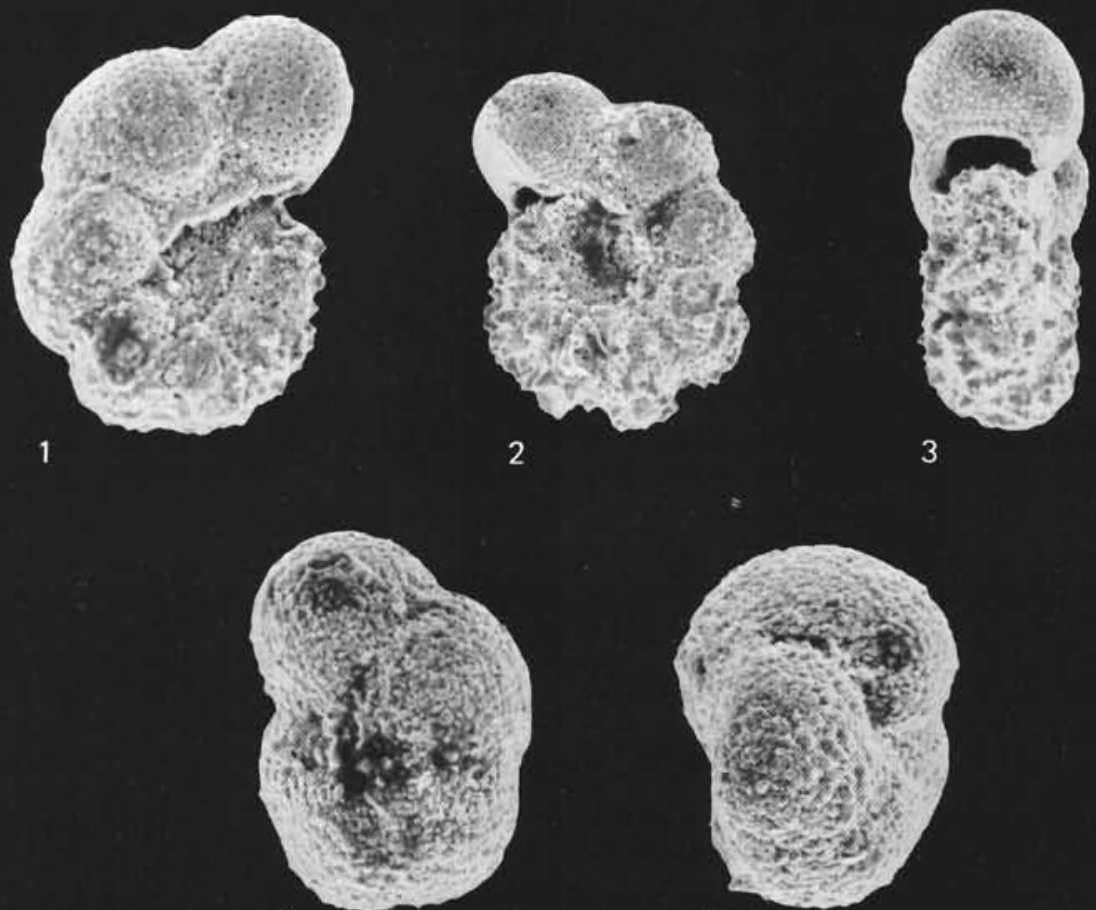

4

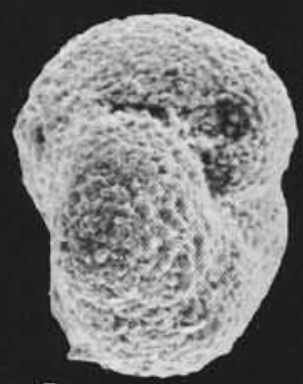

5
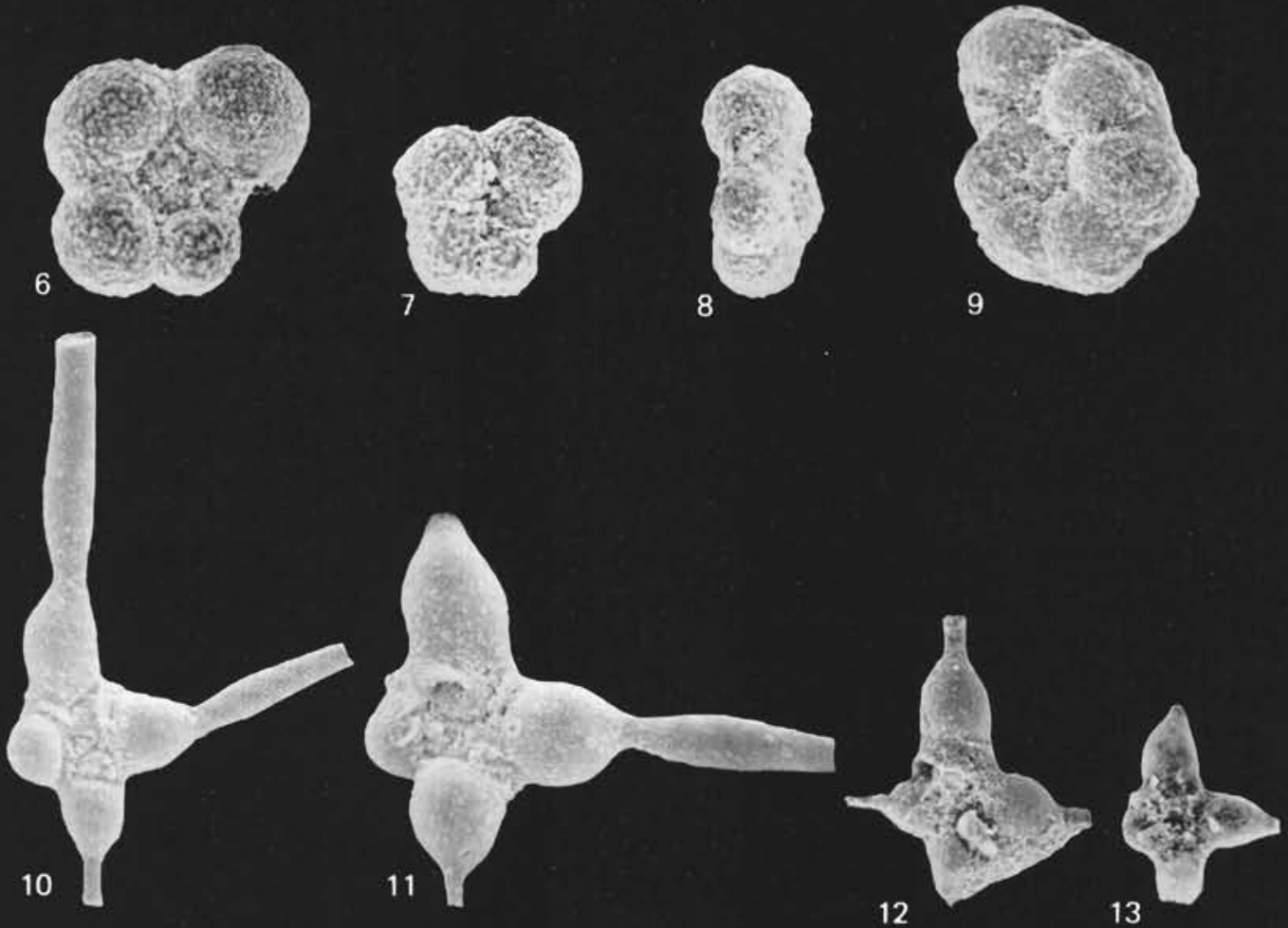
PLATE 2

Figures 1-3 Hedbergella amabilis Loeblich and Tappan.

Sample 417D-17-1, 13-15 cm, uppermost Albian to lower Cenomanian.

1. Spiral view, $\times 180$.

2. Umbilical view, $\times 180$.

3. Edge view, $\times 180$.

Figures 4, 5 Hedbergella libyca Barr.

Sample 418B-27-1, 82-84 cm, lower Cenomanian.

4. Spiral view, $\times 120$.

5. Umbilical view, $\times 120$.

Figures 6-8 Hedbergella delrioensis (Carsey).

Sample 417D-17-1, 13-15 cm, uppermost Albian to lower Cenomanian.

6. Spiral view, $\times 170$.

7. Umbilical view, $\times 170$.

8. Edge view, $\times 170$. 

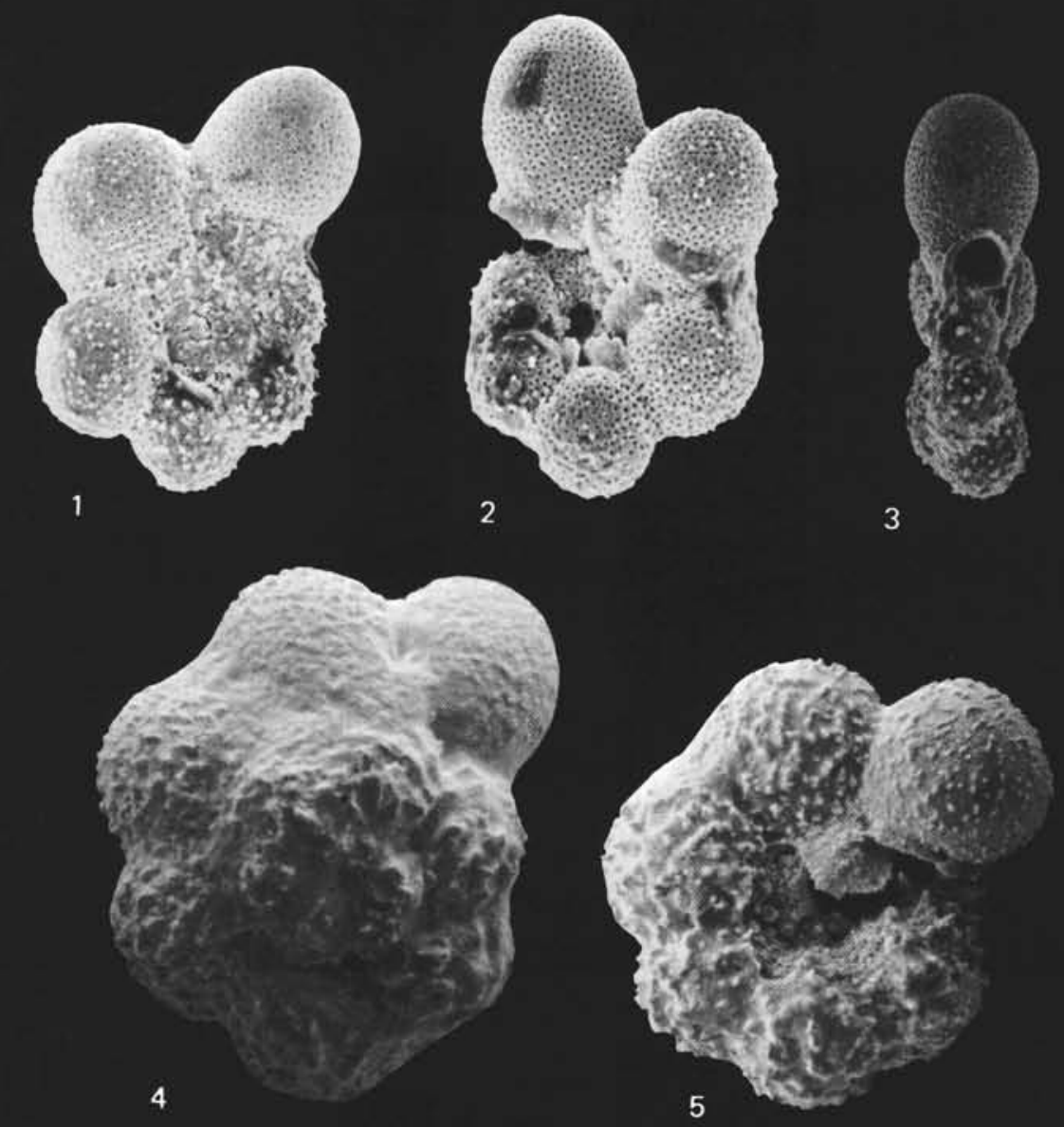

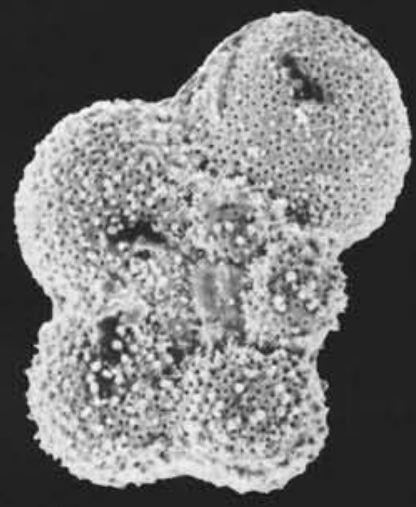

6

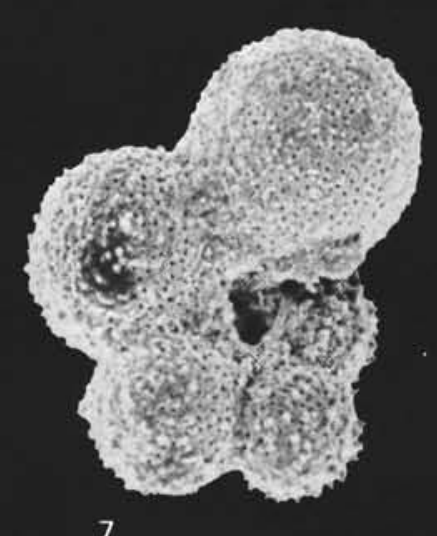

7

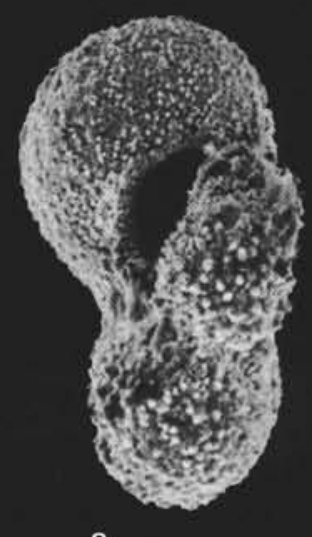

8 


\section{PLATE 3}

Figures 1-4 Hedbergella planispira (Tappan).

Sample 417D-17-1, 10-12 cm, uppermost Albian to lower Ceomanian.
1. Spiral view, $\times 230$.
2. Spiral view, $\times 230$.
3. Umbilical view, $\times 230$.
4. Edge view, $\times 200$.

Figures 5,6 Hedbergella sigali Moullade.

Sample 417D-21-3, 133-135 cm, lower Aptian.

5. Spiral view, $\times 250$.

6. Umbilical view, $\times 250$.

Figures 7-9 Hedbergella similis Longoria.

Sample 417D-23-1, 133-135 cm, lower Aptian.

7. Spiral view, $\times 200$.

8. Umbilical view, $\times 200$.

9. Edge view, $\times 170$.

Figures 10-14 Hedbergella trocoidea (Gandolfi).

10. Spiral view, $\times 170$. Sample 418 A-12, CC, lower to middle Albian.

11. Umbilical view, $\times 170$. Sample 418 A-12, CC, lower to middle Albian.

12. Umbilical view of unusually large specimen, $\times 170$. Sample 417D-20-2, 20-22 cm, lower to middle Albian.

13. Edge view, $\times 170$. Sample 417D-20-2, 20-22 $\mathrm{cm}$, lower to middle Albian.

14. Edge view, $\times 170$. Sample 418A-12, CC, lower to middle Albian. 


\section{PLATE 3}
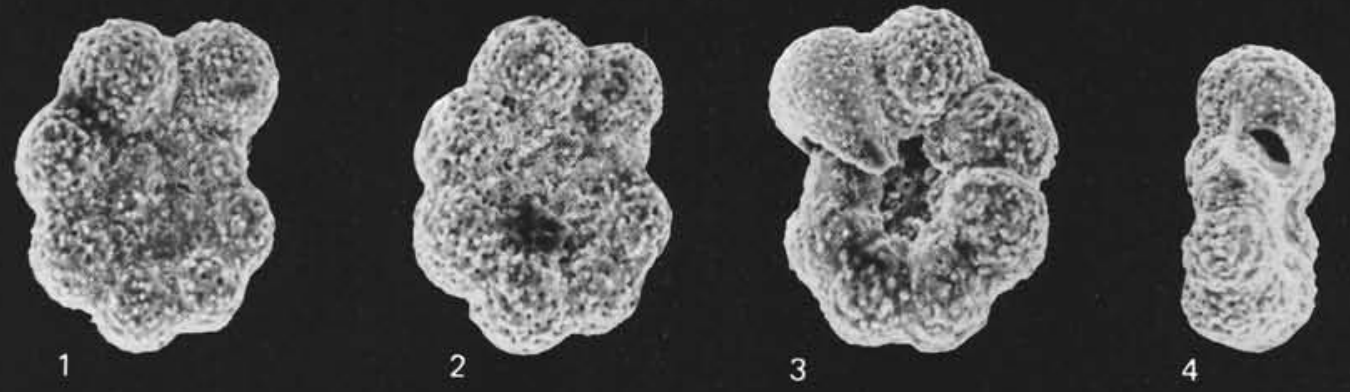

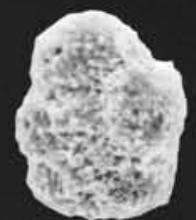

5

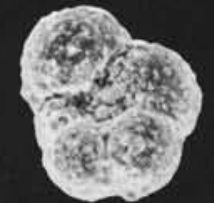

6

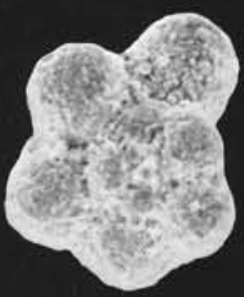

7

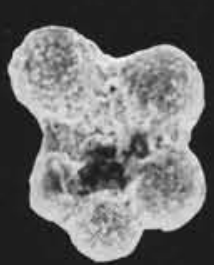

8

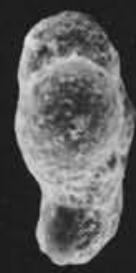

9
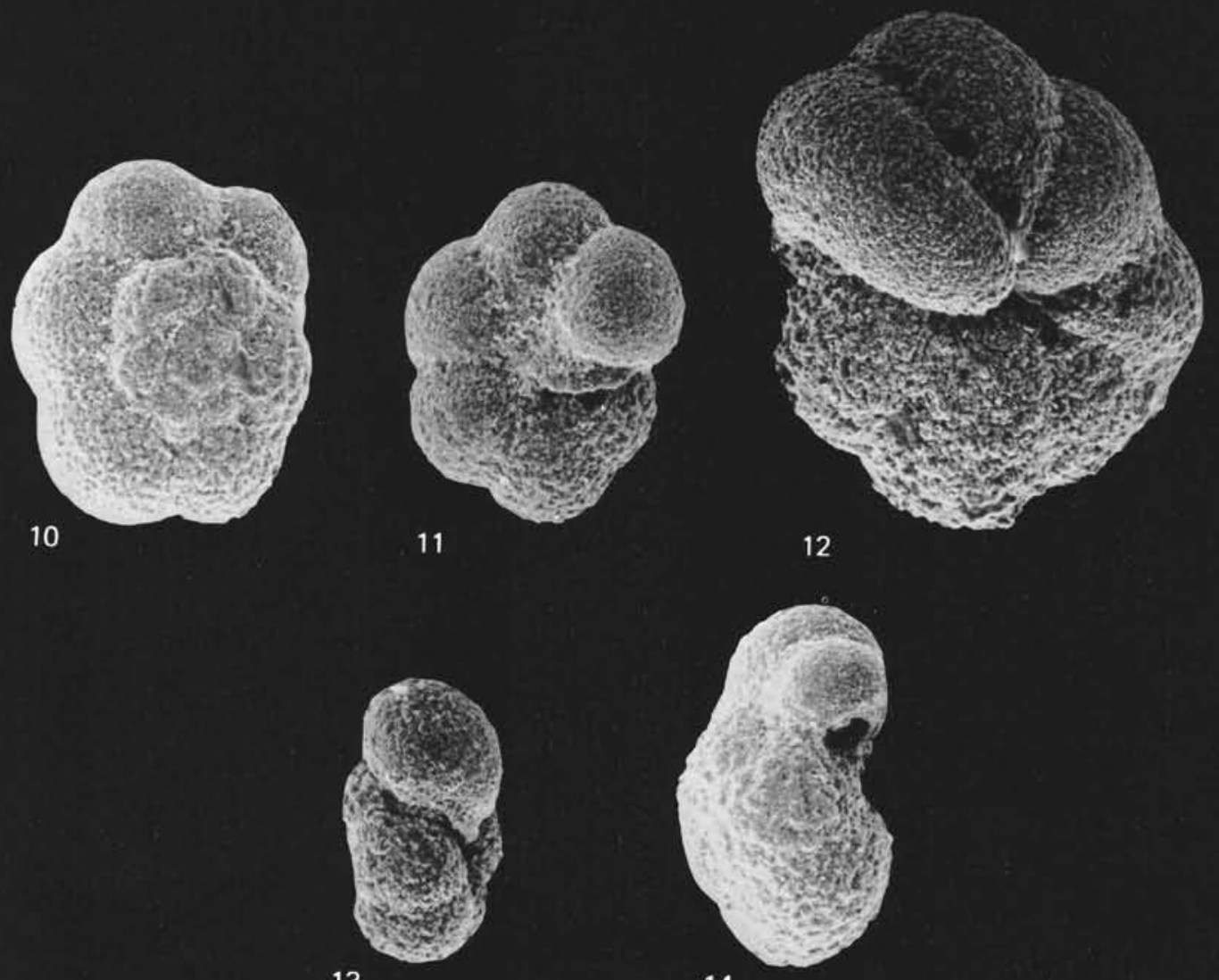

13 


\section{PLATE 4}

Figures 1-3 Hedbergella yezoana Takayanagi and Iwamoto. Sample 417D-17-1, 3-5 cm, uppermost Albian to lower Cenomanian.

1. Spiral view, $\times 170$.

2. Umbilical view, $\times 170$.

3. Edge view, $\times 170$.

Figures 4-7 Clavihedbergella moremani (Cushman).

4. Spiral view, $\times 140$. Sample $417 \mathrm{D}-17-1,3-5 \mathrm{~cm}$, uppermost Albian to lower Cenomanian.

5. Spiral view, $\times 140$. Sample 417D-17-1, 3-5 cm, uppermost Albian to lower Cenomanian.

6. Spiral view, $\times 140$. Sample 417D-17-1, 13-15 $\mathrm{cm}$, uppermost Albian to lower Cenomanian.

7. Umbilical view, $\times 140$. Sample $417 \mathrm{D}-17-1$, 13-15 cm, uppermost Albian to lower Cenomanian.

Figures 8-10 Clavihedbergella simplex (Morrow).

Sample 417D-17-1, 10-12 cm, uppermost Albian to lower Cenomanian.

8. Spiral view, $\times 230$.

9. Umbilical view, $\times 230$.

10. Edge view, $\times 230$.

Figures 11, 12 Praeglobotruncana delrioensis (Plummer). Sample 418B-27-1, 82-84 cm, lower Cenomanian.

11. Spiral view, $\times 140$.

12. Umbilical view, $\times 140$. 
PLATE 4
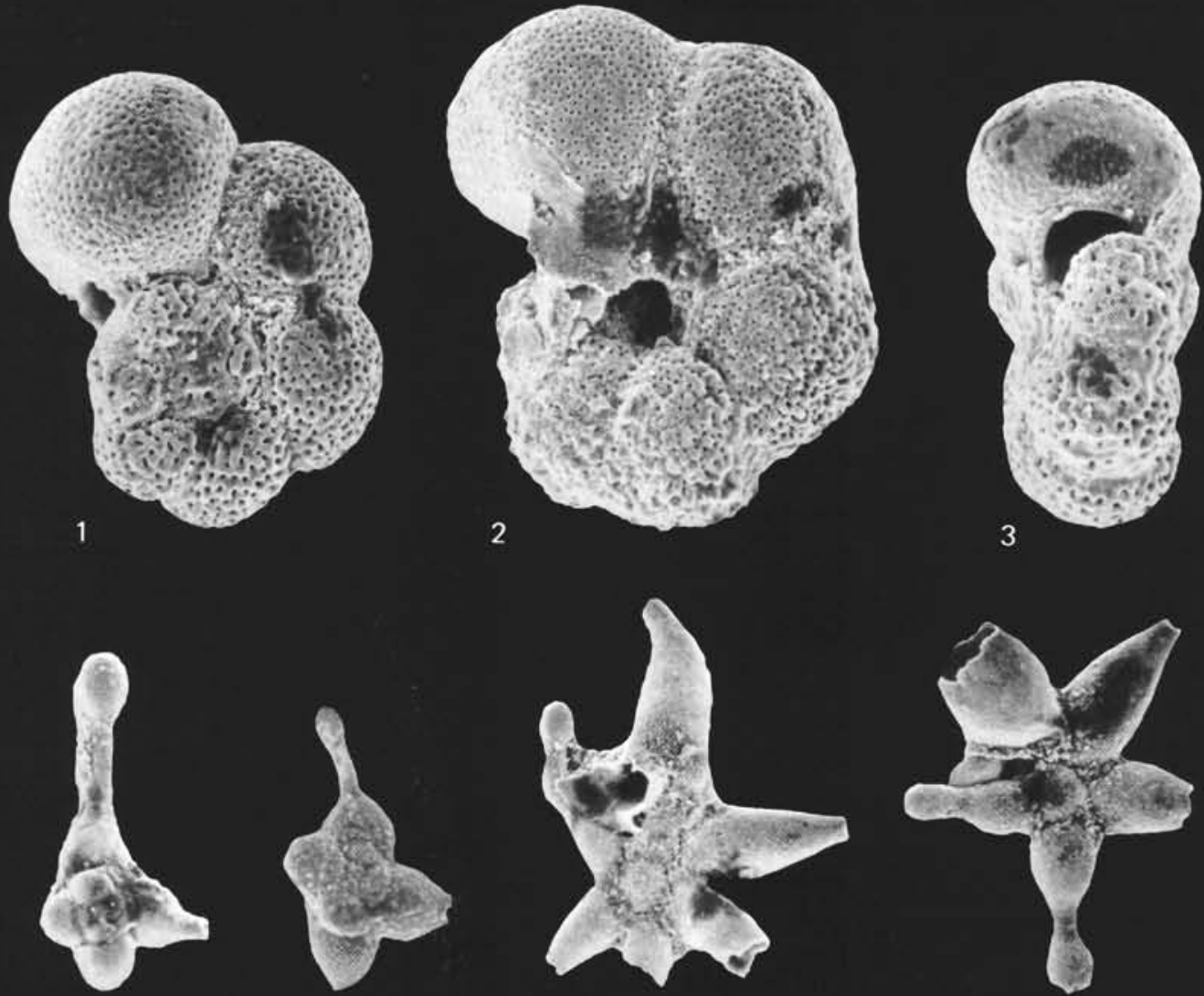

5

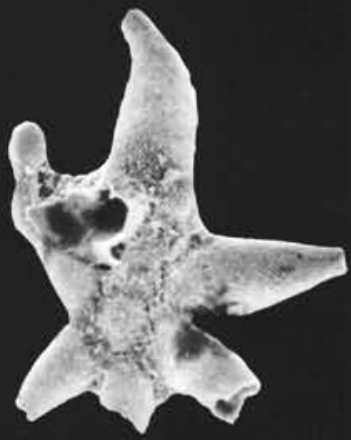

6

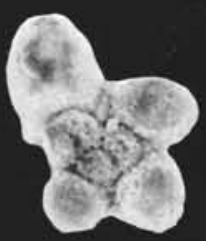

8
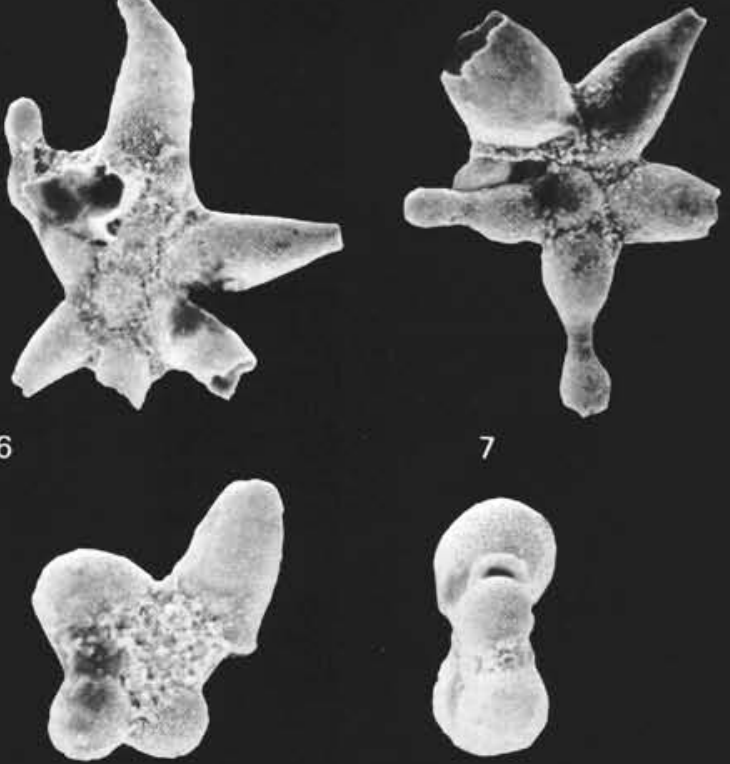

7

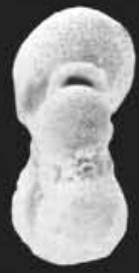

9

10
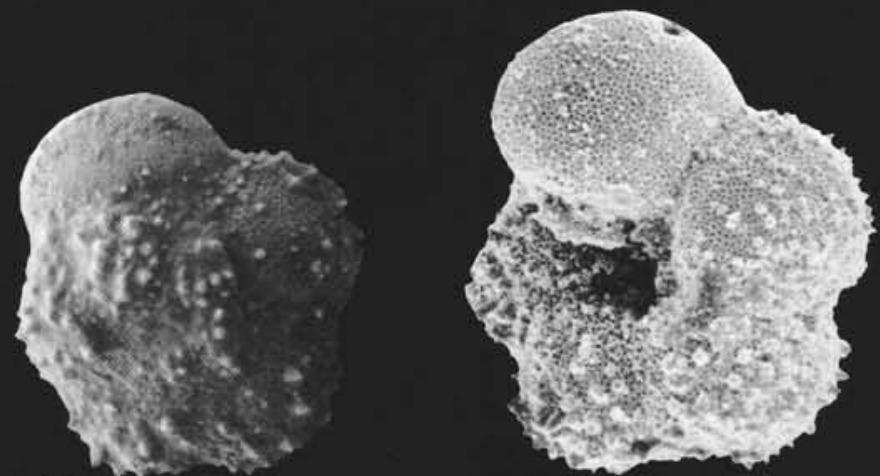


\section{PLATE 5}

Figures 1-3 Rotalipora evoluta (Sigal).

Sample 418B-27-1, 82-84 cm, lower Cenomanian.

1. Spiral view, $\times 140$.

2. Umbilical view, $\times 140$.

3. Edge view, $\times 140$.

Figures 4-7 Rotalipora ticinensis (Gandolfi).

Sample 417D-17-1, 13-15 cm, uppermost Albian to lower Cenomanian.

4. Spiral view, $\times 140$.

5. Umbilical view, $\times 140$.

6. Umbilical view, $\times 140$.

7. Edge view, $\times 140$. 


\section{PLATE 5}
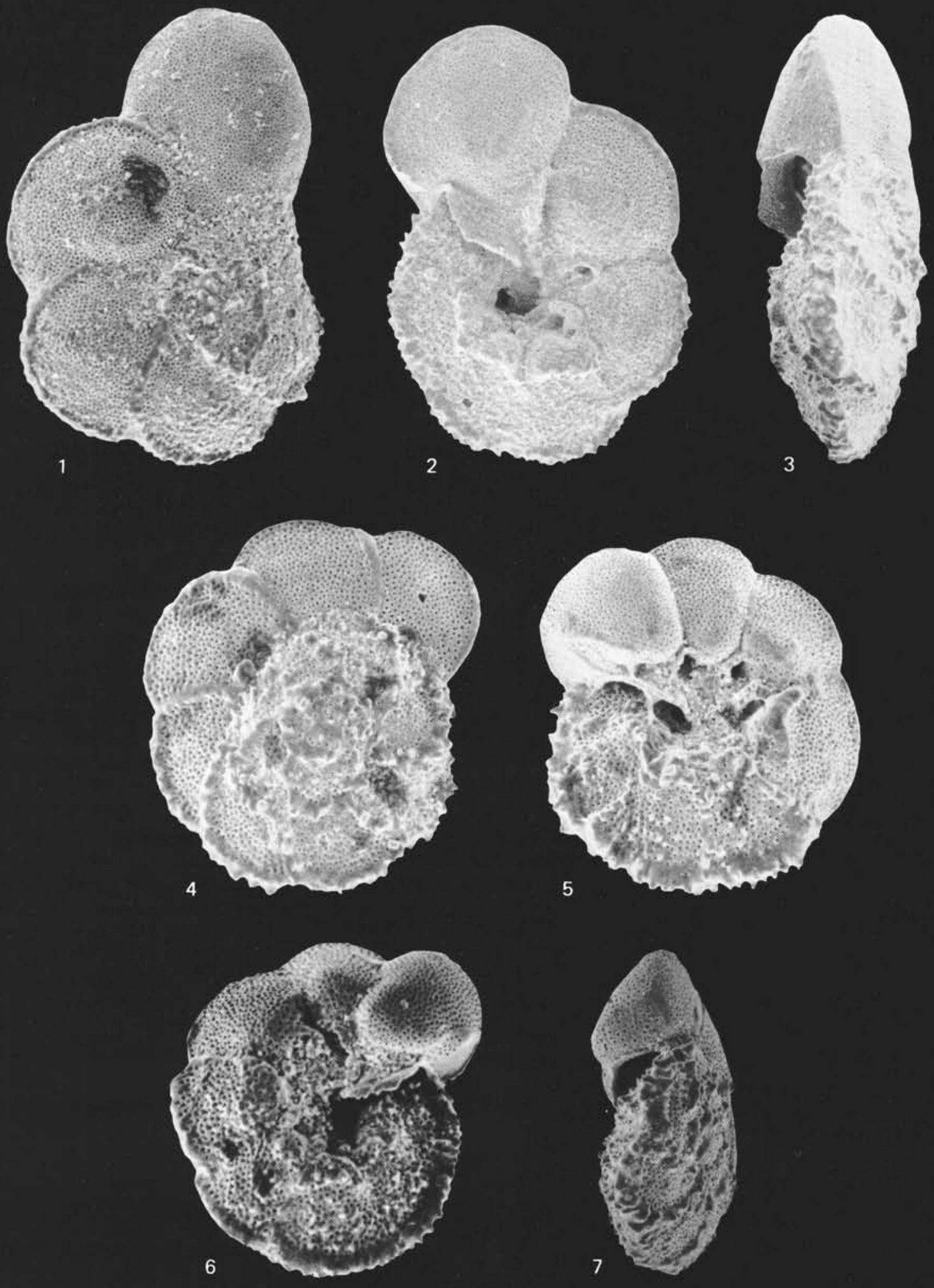


\section{PLATE 6}

Figures 1, 2 Ticinella breggiensis (Gandolfi).

Sample 417D-20-2, 20-22 cm, lower to middle Albian.

1. Umbilical view, $\times 140$.

2. Edge view of same specimen, $\times 140$.

Figures 3-7 Ticinella praeticinensis Sigal.

3. Spiral view, $\times 140$. Sample 418 A-10-1, $50-52 \mathrm{~cm}$, upper Albian.

4. Umbilical view of same specimen, $\times 140$.

5. Spiral view, $\times 140$. Sample 418B-28-2, 106-108 $\mathrm{cm}$, upper Albian.

6. Umbilical view, $\times 140$. Sample 418B-28-2, 106$108 \mathrm{~cm}$, upper Albian.

7. Edge view, $\times 140$. Sample 418B-28-2, 106-108 $\mathrm{cm}$, upper Albian. 

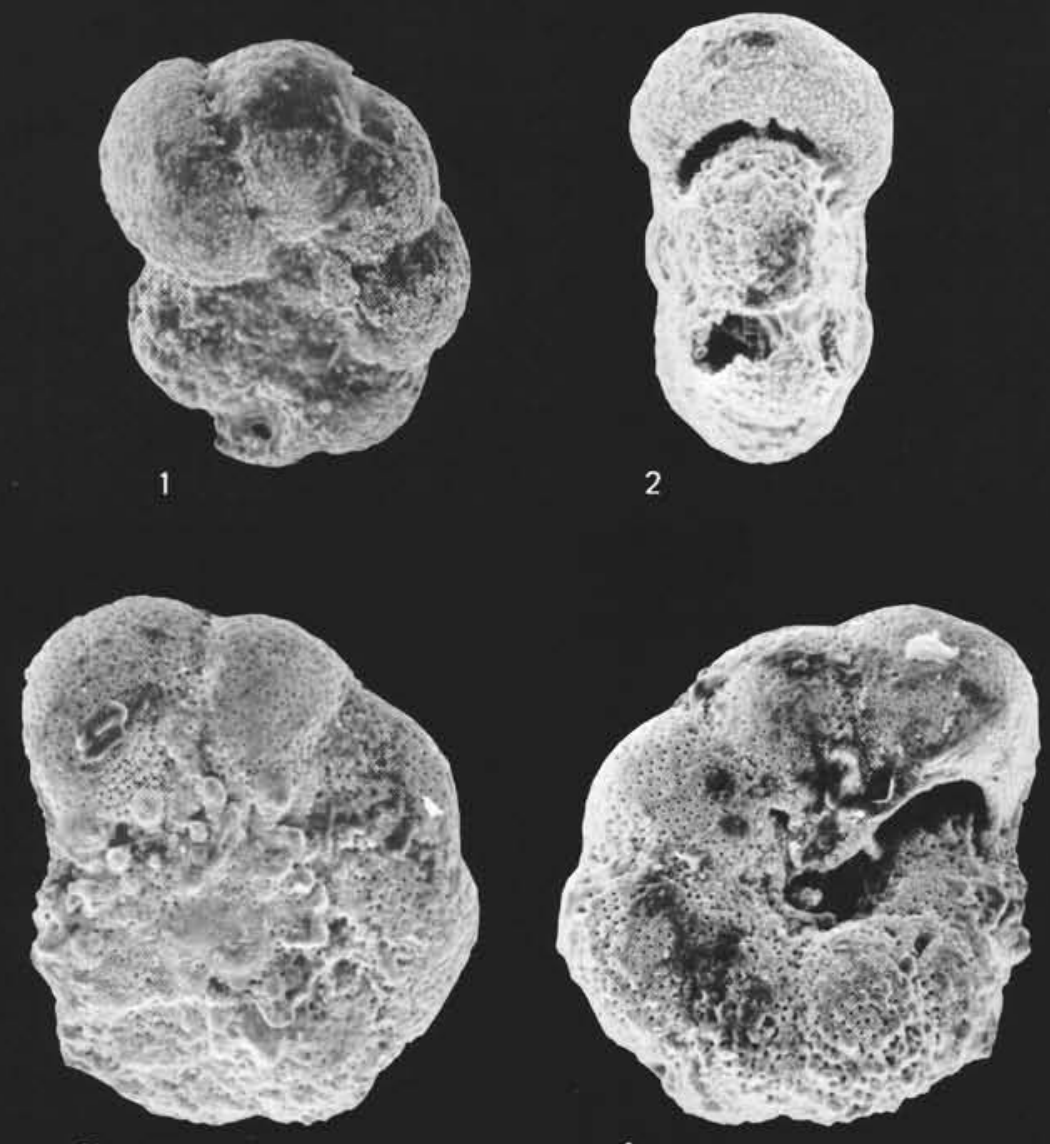

4

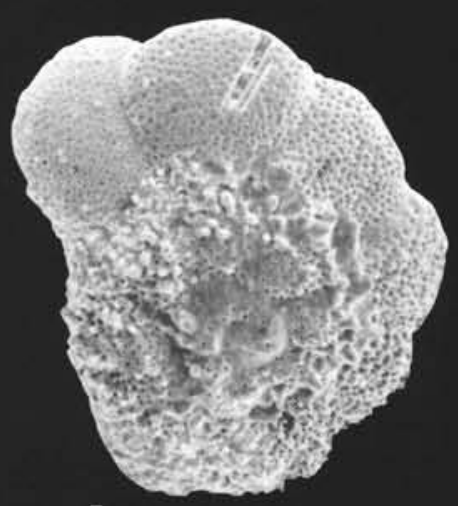

5

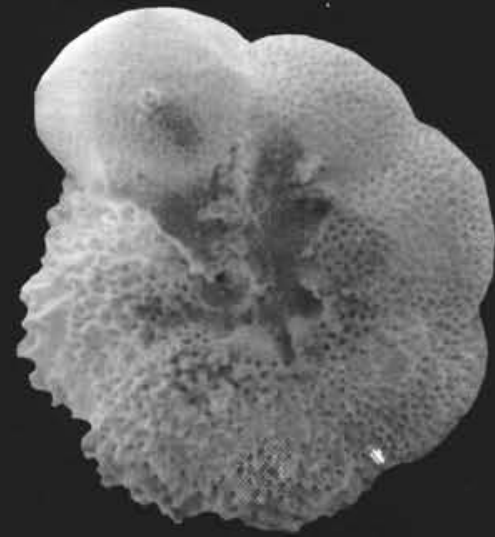

6

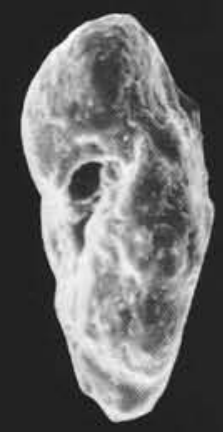

7 